\title{
Review Paper: \\ Negative Factors Affecting the Sleep Quality of the Elderly in Iran: A Sys- tematic Review
}

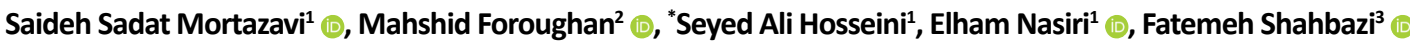

1. Department of Occupational Therapy, School of Rehabilitation Sciences, University of Social Welfare and Rehabilitation Sciences, Tehran, Iran

2. Iranian Research Center on Aging, University of Social Welfare and Rehabilitation Sciences, Tehran, Iran.

3. Department of Epidemiology, School of Public Health, Hamadan University of Medical Sciences, Hamadan, Iran.

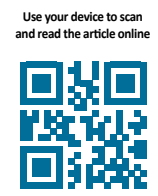

Citrat on Mortazavi SS, Foroughan M, Hosseini SA, Nasiri E, Shahbazi F. [Negative Factors Affecting the Sleep Quality of the Elderly in Iran: A Systematic Review (Persian)]. Archives of Rehabilitation. 2021; 22(2):132-153. https://doi.org/10.32598/ RJ.22.2.3011.1

doi'https://doi.org/10.32598/RJ.22.2.3011.1

Received: 23 Sep 2020

Accepted: 19 Dec 2020

Available Online: $01 \mathrm{Jul} 2021$

Keywords:

Aging, Sleep disorder Iran

\section{A B STRACT}

Objective As age increases, different physical and mental problems, including sleep disorders, occur in the elderly. The Person-Environment-Occupation (PEO) model is one of the most common practical models in occupational therapy. The current study aims to review negative factors affecting the sleeping quality of the elderly in Iran based on the PEO model.

Materials \& Methods According to PRISMA (the preferred reporting items for systematic reviews and meta-analyses) guidelines and in this systematic review study, we searched Google Scholar, Scopus, PubMed, Magiran, IranMedex, and SID databases using the keywords of "Elderly", "aging", "geriatric", "older adult", "Iran", and "sleep" in English and Persian articles published from 2010 to 2019. Studies on the sleep problems of other age groups, letters to the editor, duplicate studies, studies on non-Iranian seniors, studies published in languages other than Persian and English, and those with unavailable fulltexts were excluded. In the next stage, the titles and abstracts of the retrieved articles were independently reviewed by two researchers to identify the studies that meet the inclusion criteria. The dispute was resolved through discussion and reaching an agreement. Then, the full text of eligible articles was retrieved. Articles approved based on at least 20 out of 22 items of the STROBE (strengthening the reporting of observational studies in epidemiology) checklist were included in the study. Finally, 24 articles that were in line with the research objectives were selected for an in-depth review.

Results Out of 24 studies, 11 reported quantitative sleep problems, 9 of which claimed that more than $70 \%$ of the elderly had sleep problems. The negative factors affecting the sleep quality of Iranian older adults were presented and categorized based on personal, environmental, and occupational factors. Eighteen articles addressed personal factors, where the most common factor was related to personal health issues. Eleven articles reported environmental factors, where the most common factor was related to the physical environment. In three articles, the factors that had a negative effect on sleeping are occupational and included the change of sleeping place and not talking to others before going to bed.

Conclusion Personal factors (e.g. aging, female gender, disease), environmental factors (e.g. lack of communication with relatives and friends, inappropriate physical environment, and living in a nursing home), and occupational factors (e.g. change of sleeping place, hospitalization, and not talking to others before going to sleep) are negative factors affecting the sleep quality of the elderly in Iran.

\section{* Corresponding Author:}

Seyed Ali Hosseini, PhD. Candidate

Address: Department of Occupational Therapy, School of Rehabilitation Sciences, University of Social Welfare and Rehabilitation Sciences, Tehran, Iran.

Tel: +98 (912) 3907872

E-Mail: alihosse@gmail.com 


\section{Extended Abstract}

\section{Introduction}

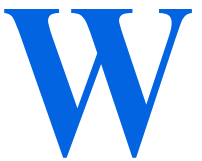

ith the increase in the elderly population, the problems of this group are more emphasized [1]. In 2015, the number of people aged 60 years or older was about 900 million, and this number will reach about

2 billion by 2050 [2]. In 2016, the aging population of Iran comprised $9.28 \%$ of the total population and was estimated to reach $25 \%-30 \%$ by 2031 [3]. Sleep disorders are one of the problems related to old age [4]. Sleep is a complex and dynamic physiological state. Sleep deprivation causes neurological, autonomic, and biological changes. With aging, the prevalence of sleep problems increases [5]. Inability to sleep well at night can affect the quality of life; increase the risk of depression, anxiety, and stress [5-7]; and reduce cognitive function and concentration in dealing with daily activities [8]. The prevalence of sleep disorders in the elderly is $50 \%-70 \%$, and the most common disorder is insomnia; $40 \%$ of people over 60 years of age complain of difficulty falling asleep or staying asleep [9]. Poor quality sleep, after headaches and digestive disorders, is the third most common problem in the elderly [6]. Sleep disorders can cause fatigue problems, headaches, impaired concentration, irritability, drowsiness, poor memory, unstable mood, increased response time and decreased performance levels [10]. These consequences expose the elderly to greater risks such as falls, cognitive and psychological disorders, poor physical function, decreased quality of life, increased dependence and vulnerability, and ultimately death [11]. Numerous factors such as gender, age, employment status, marital status, socio-economic status, place of residence, physical health, mental health, and nutritional status can be effective in causing sleep disorders, most important of which is age [12].

The Person-Environment-Occupation (PEO) model is a common and practical model in occupational therapy which consists of three domains of person, environment, and occupation. According to the Occupational Therapy Practice Framework (OTPF), the person domain includes all the characteristics that describe the unity of the person [13]. The environment domain includes cultural, institutional, virtual, physical, and social environments [13]. The occupation refers to a purposeful activity that is meaningful to a person and has value and importance. The mental and physical performance is always performed within a visible set of physical, social, and cultural conditions in the environment (workplace) and by a person with a developmental structure, goals, and unique meanings that have consequences for the environment. The result of a dynamic interaction between these components forms the function of occupation [14].
Due to the lack of a comprehensive study summarizing the mentioned factors and given the different prevalence rates of sleep disorders in the elderly in various countries (e.g. $35.9 \%$ in China [15], 23\% in Germany [16], and 52.2\% in Iran [17]), this study aims to review the negative factors affecting the sleep of Iranian elderly using the PEO model.

\section{Materials and Methods}

According to PRISMA (the Preferred Reporting Items for Systematic Reviews and Meta-Analyses) guidelines, a systematic search was conducted on related studies published in English or Persian from 2010 to 2019 in Google Scholar, PubMed, Medline, Scopus, Magiran, IranMedex, and SID databases using the keywords of "Elderly", "aging", "geriatric", "older adult", "Iran", and "sleep" in English and Persian. Studies on sleep problems of other age groups, letters to the editor, duplicate studies, studies on non-Iranian seniors, and studies published in languages other than Persian and English, and those with unavailable full-texts were excluded. Then, the titles and abstracts of the remaining studies were independently reviewed by two researchers. Afterward, the full text of all studies that met the inclusion criteria was retrieved. The full text of the selected articles was evaluated in terms of quality using the STROBE checklist (a tool designed for cross-sectional studies), and the articles approved based on at least 20 out of 22 items of the checklist were included in the study. Next, the data, including the number of samples, study location, measures, type of study, and sleep-disturbing factors, were extracted from eligible articles and recorded as shown in Figure 1.

The initial search yielded 235 articles. After checking the titles, this number was reduced to 44 due to the consideration of articles that examined the sleep quality of the elderly and the negative factors affecting it. Then, by reading the abstracts, 24 articles that were in line with the objectives of this research were selected for a deeper review.

\section{Results}

Negative factors affecting sleep quality in Iranian elderly were examined based on three PEO domains of person, environment, and occupation. Of 24 studies, 11 reported sleep problems in quantitative terms, of which 9 studies believed that more than $70 \%$ of the elderly had sleep problems. Eighteen studies reported personal factors that had a negative impact on the sleep quality of the elderly, and most studies addressed problems related to personal health (Figure 2). Eleven studies reported environmental factors with a negative impact on the sleep quality of the elderly, and most articles addressed problems related to the physical environment (Figure 2). In three articles, the factors that had 


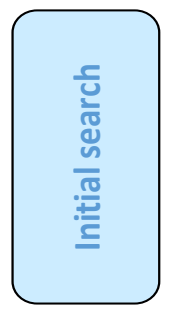

235 articles were extracted

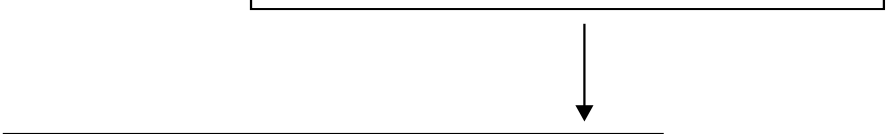

Excluding duplicates and those with unavailable full texts and not studying older adults $(n=191)$

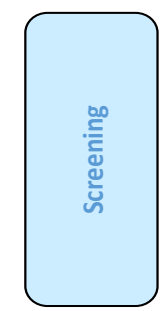

Excluding those not studying the risk factors of sleep problems $(n=12)$

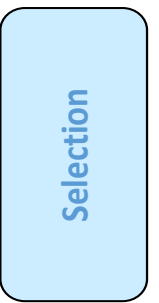

Screening the titles and abstracts of 44 remained articles

Figure 1. Flowchart of the process of selecting articles for review

Checking the full text of the articles for eligibility $(n=32)$

a negative impact on the sleeping occupation of the elderly were reported; one study reported the "change in sleeping position", and one indicated the factor of "talking before going to bed" (Figure 2). Among the reviewed studies, 8 (34\%) had been conducted in 2017, 9 (37.5\%) in Tehran City, Iran, and 95.83\% used the Pittsburgh Sleep Quality Index (PSQI). Their total sample size was 3578 (mean number $=150$, ranged from 30 to 400 ). Table 1 summarizes the reviewed studies regarding their participants, type of study, measures, and results.

\section{Discussion and Conclusion}

In the present study, the adverse factors affecting the sleep quality of the elderly were reviewed based on the PEO model, and the results of the studies were presented in three domains of person, environment, and occupation. Negative factors related to the domain of person included aging [18], female gender [19-22], mental illness in older women and barriers and physical problems in older men [23], general health problems [21, 24-26], flushing [27], deficiency of minerals in the body, including magnesium [28], having chronic and underlying diseases [29], respiratory arrest [30], comorbid diseases [29], mental illness [27, 30-34], unrelieved pain [35], joint stiffness [36], knee pain [36], obesity [33], and lower education [33, 37]. The aging process is associated with objective and subjective changes in the quantity and quality of sleep. Therefore, complaints about difficulty in falling asleep and staying awake and drowsiness are more common in older people than in other age groups [18, 23]. Mental health problems were another factor. There is a correlation between depression and sleep disorder, and if the symptoms of depression are not treated, the quality of sleep will deteriorate significantly over time [23]. Chronic diseases such as diabetes were also one of the negative personal factors affecting the sleep of the elderly. Decreased overnight glucose tolerance is associated with decreased insulin sensitivity and insulin secretion response to elevated blood glucose [38]. Studies reported that women had more sleep problems and lower sleep quality than men, which is due to hormonal changes after menopause and being physiologically and psychologically sensitive [31]. 


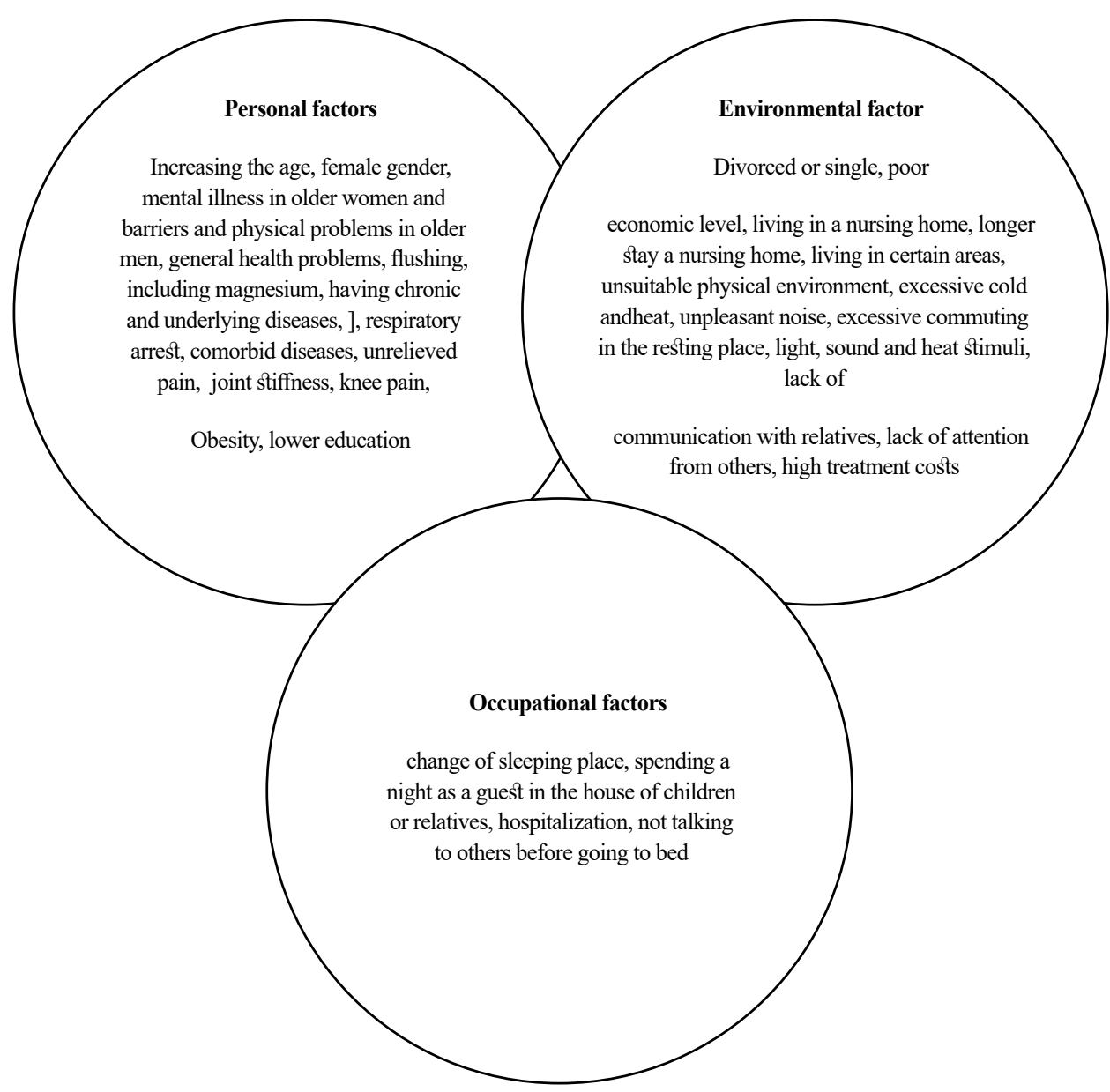

Archives of

Figure 2. Factors negatively affecting the sleep of the Iranian elderly based on the Person-Eenvironment-Occupation (PEO) model

Negative factors related to the domain of environment included being widow(ed), divorced or single [19, 39], poor economic level [37], living in a nursing home [40] and longer stay a nursing home [24, 41], living in certain areas [40], unsuitable physical environment, excessive cold and heat, unpleasant noise [42] and excessive commuting in the resting place [40], light, sound and heat stimuli [35], lack of communication with relatives [27], lack of attention from others [43], feeling lonely [27], and high treatment costs [43]. The elderly who are sent to live in nursing homes lose the support of their family, leading to their depression, feelings of futility, physical problems, and social dysfunction, and affect the quantity and quality of their sleep [36, 44, 45]. The better sleep quality of married older adults than single, widowed, or divorced ones can be related to psychological and social factors. Married people have a great source of social support, i.e., family, while single and widowed people are deprived of this support [19, 39, 45].

Negative factors related to the domain of occupation included the change of sleeping place (e.g. spending a night as a guest in the house of children or relatives) [39], hos- pitalization [19], not talking to others before going to bed, unemployment [27], inactivity and prolonged lying down during the day [46], low quality of life [40, 47], lack of aerobic exercise [47], and dependence in performing basic and instrumental activities of daily living [48]. Retired and unemployed older adults have a higher risk of developing sleep problems. Retirement is usually accompanied by external pressures such as illness or the need to take care of a sick family member. It is associated with decreased physical and mental health due to loss of job and social relations and may turn a healthy adult into a weak person by reducing various physiological capacities and increasing susceptibility to many diseases. These processes and the development of mental illnesses such as depression, cognitive disorders, fear, and addiction, provide the basis for sleep disorders [49]. Lack of physical activity also affects the quantity and quality of sleep. Physical activity increases energy consumption and improves sleep quality by secreting endocrine. Sleep increases the secretion of anabolic hormones (e.g. growth hormone, testosterone, and prolactin) and reduces the levels of catabolic hormones (e.g. cortisol) [50]. 
Table 1. Summary of the reviewed studies

\begin{tabular}{|c|c|c|c|c|c|c|}
\hline Author(s) & Study Design & Participants & Measures & Results & Negative Factors & POE Domain \\
\hline Papi et al. [36] & Cross-sectional & $\begin{array}{c}130 \text { older adults } \\
\text { living in Ahvaz } \\
\text { City, Iran }\end{array}$ & PSQI & $\begin{array}{c}\text { Sleep disorder of } 81.5 \% \text { was } \\
\text { at a moderate level; } 13.8 \% \\
\text { at a low level, and } 4.6 \% \text { at a } \\
\text { severe level }\end{array}$ & $\begin{array}{l}\text { Perceived social } \\
\text { support, joint } \\
\text { stiffness, knee } \\
\text { pain, and multiple } \\
\text { diseases }\end{array}$ & $\begin{array}{l}\text { Person, envi- } \\
\text { ronment }\end{array}$ \\
\hline $\begin{array}{c}\text { Fadayevatan et } \\
\text { al. [29] }\end{array}$ & Cross-sectional & $\begin{array}{l}200 \text { people with } \\
\text { type } 2 \text { diabetes } \\
\text { referred to a } \\
\text { clinic in Kerman } \\
\text { City, Iran }\end{array}$ & PSQI & $\begin{array}{c}\text { The overall sleep quality of } \\
63.8 \% \text { was poor }\end{array}$ & $\begin{array}{l}\text { Lack of mental } \\
\text { health, poorly } \\
\text { controlled blood } \\
\text { sugar }\end{array}$ & $\begin{array}{l}\text { Person, envi- } \\
\text { ronment }\end{array}$ \\
\hline
\end{tabular}

$\begin{array}{ccc}\begin{array}{c}\text { Sadri Damirchi } \\ \text { et al. [43] }\end{array} & \begin{array}{c}\text { Descriptive/ } \\ \text { correlational }\end{array} & \begin{array}{c}\text { adults in a nurs- } \\ \text { ing home in } \\ \text { Ardabil City, Iran }\end{array}\end{array}$

\section{Mirzaei et al.}

\section{Older adults in}

Yazd City, Iran
Sleep quality was poor, and there was a significant and PSQI direct relationship between sleep quality and attention under the Stroop test

\section{Decreased atten-} tion

Environment

$\begin{array}{ccc} & & \\ \text { Farokhnezhad } & \text { Quasi-experi- } & \begin{array}{c}30 \text { older adults } \\ \text { hospitalized in a } \\ \text { Coronary Care } \\ \text { Afshar et al. }\end{array} \\ \text { [42] } & \text { mental } & \begin{array}{c}\text { Unit in Tehran } \\ \text { City, Iran }\end{array}\end{array}$

\section{PSQ Sleep quality of $75 \%$ was} poor
Being single, lower

education, chronic Person, envi-

illness, poor eco- ronment nomic status
White noise did not significantly change the sleep quality of old patients

PSQI however, it prevented the decrease in sleep duration and the increase in sleep latency duration.

\begin{tabular}{|c|c|c|c|c|c|c|}
\hline $\begin{array}{l}\text { Bahrami et al. } \\
\qquad[41]\end{array}$ & Cross-sectional & $\begin{array}{l}34 \text { older adults in } \\
\text { a nursing home } \\
\text { in Damghan } \\
\text { County, Iran }\end{array}$ & PSQI & $\begin{array}{c}\text { Sleep quality of } 73.5 \% \text { was } \\
\text { poor. }\end{array}$ & $\begin{array}{l}\text { Female gender, } \\
\text { being single, longer } \\
\text { stay in a nursing } \\
\text { home }\end{array}$ & $\begin{array}{l}\text { Person, envi- } \\
\text { ronment }\end{array}$ \\
\hline Baghi et al. [30] & $\begin{array}{c}\text { Analytical/ } \\
\text { cross-sectional }\end{array}$ & $\begin{array}{c}300 \text { older } \\
\text { adults in Saqqez } \\
\text { County, Iran }\end{array}$ & $\begin{array}{l}\text { STOP sleep } \\
\text { apnea } \\
\text { question- } \\
\text { naire }\end{array}$ & $71 \%$ had sleep apnea & Sleep apnea & Person \\
\hline $\begin{array}{l}\text { Pakpour et al. } \\
{[48]}\end{array}$ & $\begin{array}{l}\text { Descriptive/ } \\
\text { observational }\end{array}$ & $\begin{array}{l}300 \text { older adults } \\
\text { in Zanjan City, } \\
\text { Iran }\end{array}$ & PSQI & $\begin{array}{c}\text { Sleep quality of } 85.7 \% \text { was } \\
\text { poor. }\end{array}$ & $\begin{array}{l}\text { Dependence in } \\
\text { performing basic } \\
\text { and instrumental } \\
\text { activities of daily } \\
\text { living }\end{array}$ & Environment \\
\hline
\end{tabular}

Unpleasant sound Person hospitalization environment, occupation
The sleep quality of the elderly in the southern regions of Tehran was better

90 older adults in

Beh Pajoh et al. Descriptive/ a nursing home [47] analytical in Tehran City, Iran
PSQ than in the northern and central regions. By improving the quality of life, sleep quality improves.
Poor quality of life, living in the north of Tehran
Person, environment
Eight weeks of laughter yoga exercise was influential on the subjective quality of sleep and latency in sleeping 


\begin{tabular}{|c|c|c|c|c|c|c|}
\hline Author(s) & Study Design & Participants & Measures & Results & Negative Factors & POE Domain \\
\hline $\begin{array}{l}\text { Khodabakhshi- } \\
\text { Koolaee et al. } \\
\text { [32] }\end{array}$ & $\begin{array}{l}\text { Quasi-exper- } \\
\text { imental with } \\
\text { a pretest-post- } \\
\text { test design }\end{array}$ & $\begin{array}{l}30 \text { older women } \\
\text { in a nursing } \\
\text { home in Tehran } \\
\text { City, Iran }\end{array}$ & PSQI & $\begin{array}{l}\text { Listening to relaxation and } \\
\text { instrumental music by } \\
\text { Arnd Stein for } 12 \text { sessions } \\
\text { for } 45-50 \text { minutes could } \\
\text { improve sleep quality in } \\
\text { older women. }\end{array}$ & Tension and anxiety & Person \\
\hline $\begin{array}{l}\text { Maghsoudi et } \\
\text { al. [24] }\end{array}$ & Cross-sectional & $\begin{array}{l}120 \text { older adults } \\
\text { in Lar County, } \\
\text { Iran }\end{array}$ & PSQI & $\begin{array}{l}\text { Sleep quality of } 84.1 \% \text { was } \\
\text { poor. The sleep qual- } \\
\text { ity score was significantly } \\
\text { higher in older adults living } \\
\text { in their houses than those } \\
\text { living in nursing homes. } \\
\text { Moreover, a significant posi- } \\
\text { tive correlation was found } \\
\text { between sleep quality and } \\
\text { general health }\end{array}$ & $\begin{array}{l}\text { Decreased general } \\
\text { health, living in a } \\
\text { nursing home }\end{array}$ & $\begin{array}{l}\text { Person, envi- } \\
\text { ronment }\end{array}$ \\
\hline $\begin{array}{c}\text { Pakpour et al. } \\
\text { [50] }\end{array}$ & $\begin{array}{l}\text { Analytical/ } \\
\text { cross-sectional }\end{array}$ & $\begin{array}{l}400 \text { older adults } \\
\text { living in their } \\
\text { own houses and } \\
\text { nursing homes in } \\
\text { Tabriz City, Iran }\end{array}$ & PSQI & $\begin{array}{l}\text { Sleep quality of } 94.6 \% \text { was } \\
\text { poor. The sleep quality of } \\
\text { those living in their houses } \\
\text { was significantly higher } \\
\text { than those living in nursing } \\
\text { homes. }\end{array}$ & Loneliness & Environment \\
\hline $\begin{array}{c}\text { Kohandel et al. } \\
\text { [20] }\end{array}$ & $\begin{array}{l}\text { Causal-com- } \\
\text { parative }\end{array}$ & $\begin{array}{l}200 \text { older adults } \\
\text { in Tehran City, } \\
\text { Iran }\end{array}$ & PSQI & $\begin{array}{l}\text { Overall, sleep quality and } \\
\text { its components were better } \\
\text { in older men than in older } \\
\text { women. The participants } \\
\text { with a high level of physical } \\
\text { activity had higher PSQI } \\
\text { scores. }\end{array}$ & $\begin{array}{l}\text { Female gender, low } \\
\text { physical activity }\end{array}$ & Person \\
\hline $\begin{array}{c}\text { Khajavi et al. } \\
\text { [54] }\end{array}$ & $\begin{array}{l}\text { Two inter- } \\
\text { vention and } \\
\text { control groups }\end{array}$ & $\begin{array}{l}45 \text { older women } \\
\text { without regular } \\
\text { physical activity } \\
\text { in Arak City, Iran }\end{array}$ & PSQI & $\begin{array}{l}\text { The intervention group } \\
\text { (10 weeks, } 3 \text { sessions per } \\
\text { week, each for } 60 \text { minutes) } \\
\text { compared to the control } \\
\text { group, had a significant } \\
\text { increase in the mean overall } \\
\text { PSQI score, mental quality } \\
\text { of sleep, normal sleep effi- } \\
\text { ciency, total sleep duration, } \\
\text { daily dysfunction, and the } \\
\text { time required to fall asleep }\end{array}$ & $\begin{array}{l}\text { Stress, anxiety, } \\
\text { physical inactivity }\end{array}$ & $\begin{array}{l}\text { Person, envi- } \\
\text { ronment }\end{array}$ \\
\hline Safa et al. [21] & $\begin{array}{c}\text { Analytical/ } \\
\text { cross-sectional }\end{array}$ & $\begin{array}{l}370 \text { retired older } \\
\text { adults in Kashan } \\
\text { City, Iran }\end{array}$ & PSQI & $\begin{array}{l}\text { Sleep quality of } 27.8 \% \text { was } \\
\text { poor. Men had better sleep } \\
\text { quality than women. }\end{array}$ & $\begin{array}{l}\text { Female gender, } \\
\text { daily nap, low } \\
\text { quality of life, poor } \\
\text { health }\end{array}$ & $\begin{array}{l}\text { Person, envi- } \\
\text { ronment }\end{array}$ \\
\hline $\begin{array}{c}\text { Ahmarian et al. } \\
\text { [34] }\end{array}$ & Cross-sectional & $\begin{array}{l}30 \text { older adults in } \\
\text { Tehran City, Iran }\end{array}$ & PSQI & $\begin{array}{c}\text { Group logotherapy had a } \\
\text { significant effect on sleep } \\
\text { quality. }\end{array}$ & $\begin{array}{l}\text { Hopelessness, } \\
\text { stress }\end{array}$ & $\begin{array}{l}\text { Person, envi- } \\
\text { ronment }\end{array}$ \\
\hline $\begin{array}{c}\text { Kohandel et al. } \\
\text { [20] }\end{array}$ & Cross-sectional & $\begin{array}{l}345 \text { male older } \\
\text { adults in Tehran } \\
\text { City, Iran }\end{array}$ & PSQI & $\begin{array}{l}\text { Moderate-intensity aerobic } \\
\text { exercise had a positive ef- } \\
\text { fect on sleep quality and its } \\
\text { components }\end{array}$ & $\begin{array}{l}\text { Lack of aerobic } \\
\text { exercise }\end{array}$ & Environment \\
\hline $\begin{array}{l}\text { Farajzadeh et } \\
\text { al. [33] }\end{array}$ & $\begin{array}{c}\text { Analytical/ } \\
\text { cross-sectional }\end{array}$ & $\begin{array}{l}175 \text { depressed } \\
\text { older adults in } \\
\text { Saqqez County, } \\
\text { Iran }\end{array}$ & $\begin{array}{l}\text { Berlin } \\
\text { question- } \\
\text { naire }\end{array}$ & $\begin{array}{l}6.60 \% \text { were at high risk } \\
\text { of sleep apnea. The risk } \\
\text { of sleep apnea in obese } \\
\text { people was } 2.2 \text { times that } \\
\text { of normal-weight people }\end{array}$ & Depression, obesity & Person \\
\hline
\end{tabular}




\begin{tabular}{|c|c|c|c|c|c|c|}
\hline Author(s) & Study Design & Participants & Measures & Results & Negative Factors & POE Domain \\
\hline $\begin{array}{c}\text { Sheikhy ewt al. } \\
{[22]}\end{array}$ & $\begin{array}{c}\text { Descriptive/ } \\
\text { cross-sectional }\end{array}$ & $\begin{array}{c}100 \text { older adults } \\
\text { in Kermanshah } \\
\text { City, Iran }\end{array}$ & PSQI & $\begin{array}{c}8.39 \% \text { had sleep problems, } \\
\text { and } 2 \% \text { had severe sleep } \\
\text { problems }\end{array}$ & Female gender & Person \\
\hline $\begin{array}{c}\text { Khajavi et al. } \\
\text { [54] }\end{array}$ & $\begin{array}{c}\text { Analytical/ } \\
\text { cross-sectional }\end{array}$ & $\begin{array}{l}100 \text { older adults } \\
\text { living in their } \\
\text { own houses and } \\
\text { nursing homes in } \\
\text { Tehran City, Iran }\end{array}$ & PSQI & $\begin{array}{l}\text { Older adults living in a nurs- } \\
\text { ing home had a poor quality } \\
\text { of sleep compared to those } \\
\text { living in their own houses }\end{array}$ & $\begin{array}{l}\text { Anxiety, depres- } \\
\text { sion, physical } \\
\text { problems, social } \\
\text { dysfunction, living } \\
\text { in a nursing home }\end{array}$ & $\begin{array}{l}\text { Person, envi- } \\
\text { ronment }\end{array}$ \\
\hline $\begin{array}{c}\text { Aliasgharpoor } \\
\text { and Eybpoosh } \\
{[27]}\end{array}$ & Cross-sectional & $\begin{array}{l}164 \text { elderly resi- } \\
\text { dents of Kahrizak } \\
\text { Nursing Home in } \\
\text { Tehran City, Iran }\end{array}$ & $\begin{array}{l}\text { A } \\
\text { research- } \\
\text { er-made } \\
\text { question- } \\
\text { naire and } \\
\text { PSQI }\end{array}$ & $\begin{array}{c}88.4 \% \text { had sleep disorders } \\
\text { 140.9\% mild and } 37.2 \% \\
\text { moderate) }\end{array}$ & $\begin{array}{l}\text { Physical inactivity, } \\
\text { hot flashes, anxiety, } \\
\text { lack of contact with } \\
\text { relatives, physical, } \\
\text { mental and medi- } \\
\text { cal problems }\end{array}$ & $\begin{array}{l}\text { Person, } \\
\text { environment, } \\
\text { occupation }\end{array}$ \\
\hline $\begin{array}{c}\text { Torabi et al. } \\
{[40]}\end{array}$ & Cross-sectional & $\begin{array}{l}360 \text { older adults } \\
\text { in Jahrom City, } \\
\text { Iran }\end{array}$ & $\begin{array}{l}\text { Structured } \\
\text { research- } \\
\text { er-made } \\
\text { question- } \\
\text { naire }\end{array}$ & $\begin{array}{l}70.3 \% \text { had sleep disorders, } \\
\text { and } 81.8 \% \text { of them had } \\
\text { primary insomnia. } 94.5 \% \text { of } \\
\text { those with sleep disorders } \\
\text { had at least one non- } \\
\text { pharmacological method of } \\
\text { coping with insomnia, and } \\
7.5 \% \text { used medication }\end{array}$ & $\begin{array}{l}\text { Being single, } \\
\text { female gender, } \\
\text { unemployment } \\
\text { without income, } \\
\text { living in rural areas, } \\
\text { low education }\end{array}$ & $\begin{array}{l}\text { Person, envi- } \\
\text { ronment, }\end{array}$ \\
\hline $\begin{array}{c}\text { Abbasi et al. } \\
{[28]}\end{array}$ & $\begin{array}{l}\text { Double-blind, } \\
\text { randomized } \\
\text { clinical trial }\end{array}$ & $\begin{array}{l}46 \text { older adults in } \\
\text { Jahrom City, Iran }\end{array}$ & $\begin{array}{l}\text { Symptom } \\
\text { Checklist- } \\
\text { 90-Revised }\end{array}$ & $\begin{array}{l}8 \text { weeks of daily interven- } \\
\text { tion with } 500 \text { mg of magne- } \\
\text { sium increased the duration } \\
\text { and efficiency of sleep and } \\
\text { decreased the severity of } \\
\text { insomnia and sleep time; } \\
\text { while did not affect the } \\
\text { bedtime, wake-up time, and } \\
\text { serum magnesium levels. }\end{array}$ & $\begin{array}{l}\text { Magnesium defi- } \\
\text { ciency }\end{array}$ & Person \\
\hline
\end{tabular}

PSQI: Pittsburgh Sleep Quality Index; POE: Person-Environment-Occupation.

Archives of
Rehabilitation

The body's metabolism and catabolic activity are increased during exercise to produce energy. Exercise is a stimulant to facilitate sleep and increase anabolic activity. Regular physical activity also increases physiological efficiency by reducing visceral fat and plays a role in deepening sleep. It increases the secretion of lactic acid in the body, which increases the body's need for rest [49]. In three review studies conducted in other countries, the effect of cognitive performance [51], exercise [52], bright light, cognitive behavioral therapy, and movement exercises on sleep disorders in the elderly [53] have been indicated.

Personal factors such as age, female gender, chronic diseases, mental illness, and musculoskeletal disorders in the elderly are effective in causing sleep disorders in the Iranian elderly. Environmental factors such as Lack of communication with relatives and friends, inadequate physical environment, living in a nursing home, and the presence of sound, heat, and light stimuli also have adverse effects on their sleep. Finally, the factors of change of sleeping place, hospitaliza- tion, and not talking to others before going to bed are among the occupational factors that adversely affect sleep quality in the elderly. In intervention and counseling, therapists need to consider these personal, environmental, and occupational factors. Management approaches and training programs should be developed at different levels for the elderly.

\section{Ethical Considerations}

\section{Compliance with ethical guidelines}

This article is a meta-analysis with no human or animal sample. The present study is descriptive research (Code IR.UMSHA.REC.1398.746).

\section{Funding}

This study was extracted from a research project (with number 9809196978), financially supported by the Deputy 
for Research and Technology of Hamadan University of Medical Sciences.

Authors' contributions

All authors contributed equally in preparing this article.

\section{Conflict of interest}

The authors declared no conflict of interest.

Acknowledgments

The authors would like to thank the Vice-Chancellor for Research and Technology of Hamadan University of Medical Sciences for their support. 
This Page Intentionally Left Blank 


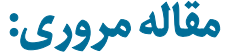 \\ عوامل منفي تأثير كَّْار بر خواب سالمندان ايراني: يك مطالعه مرورى

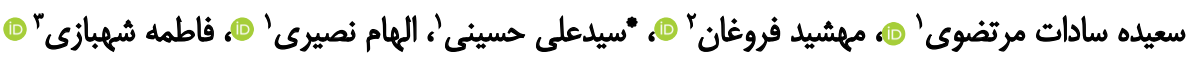 \\ ا. كروه كاردرمانى، دانشكده علوم توانبخشى، دانشكاه علوم توانبخشى و سلامت اجتماعى، تهران، ايران.

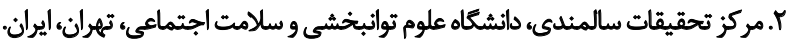

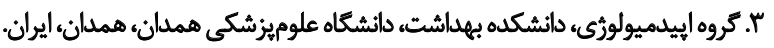

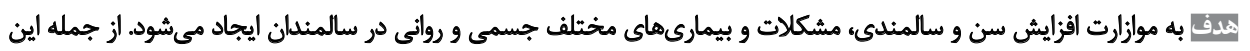

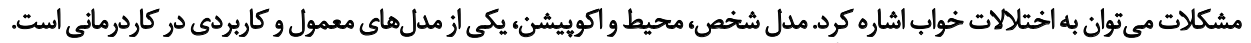

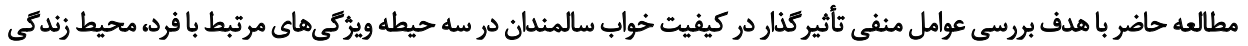

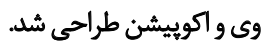

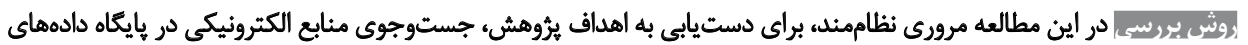

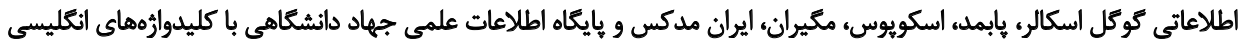

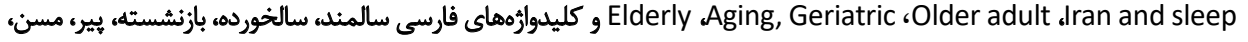

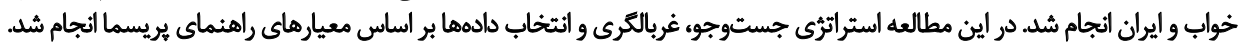

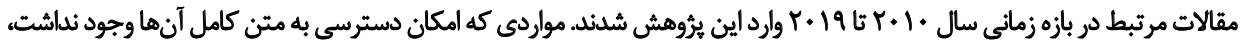

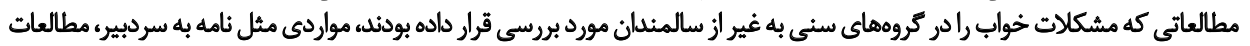

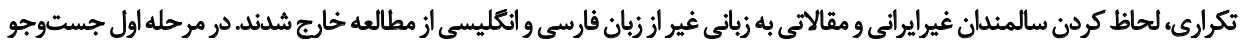

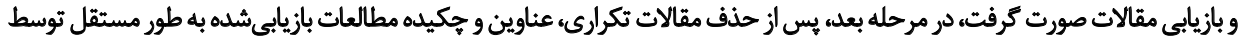

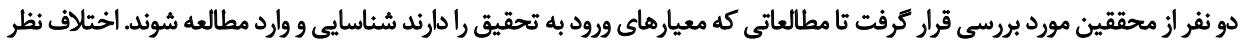

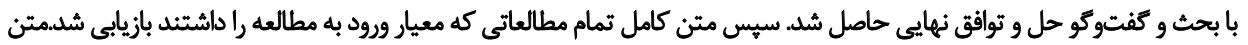

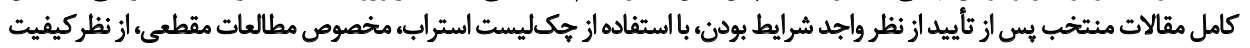

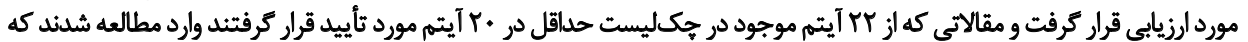

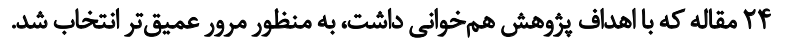

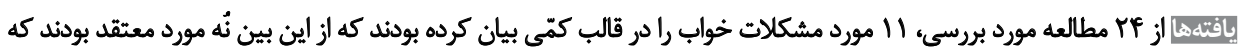

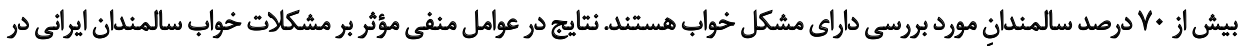

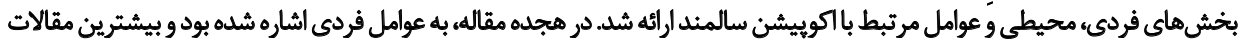

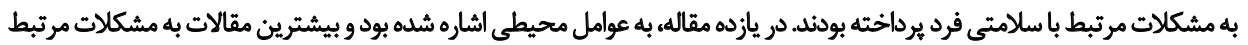

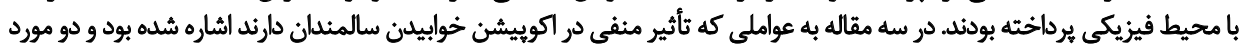

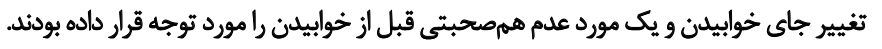

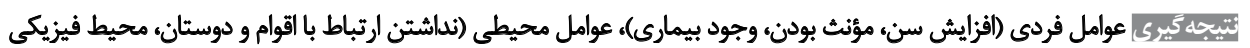

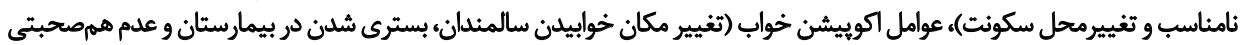

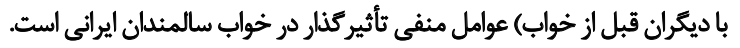

تاريخ دريافت: r. مهر 1499

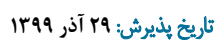

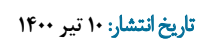

كليدوارٔهها:

كهنسال، اختيلالات

خواب، ايران 
سطح عملكرد شود [ [ []] . اين ييامدها باعث مىشود سالمندان در معرض خطرات بيشترى نظير سقوط، اختلالات شناختى و و وروانى،

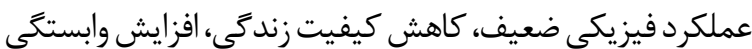

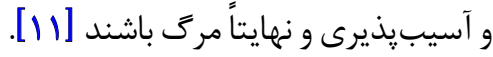

رايمن و همكاران، عوامل متعددى نظير جنس، سن، وضعيت

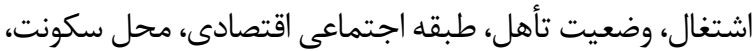

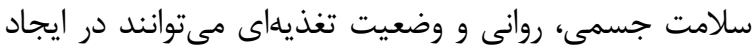

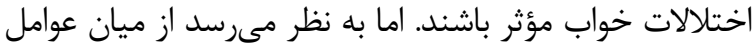

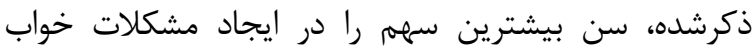

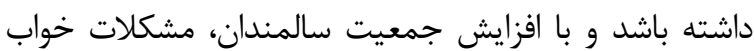

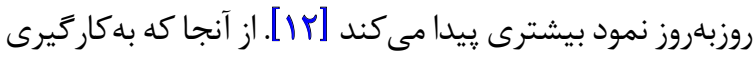

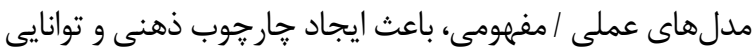

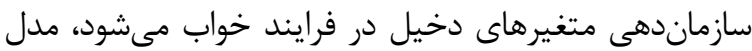

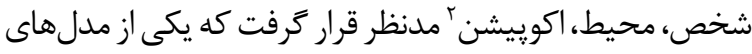

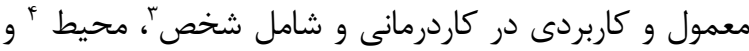

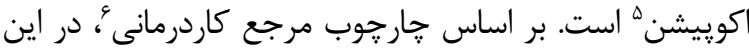

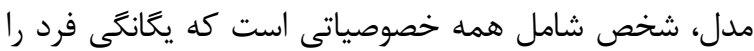

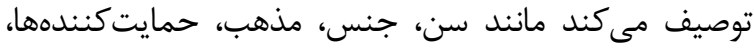

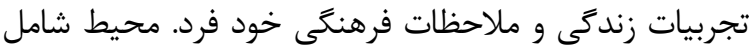

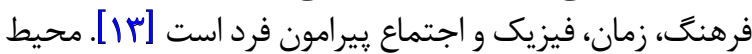

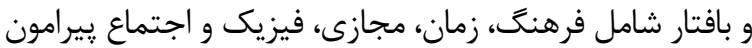

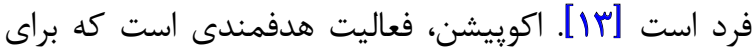

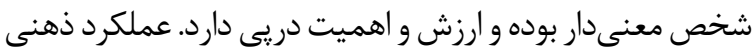

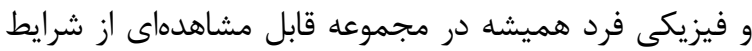

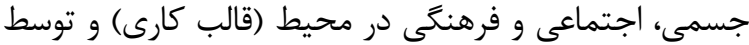

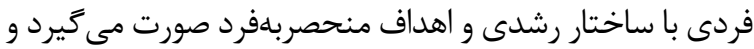

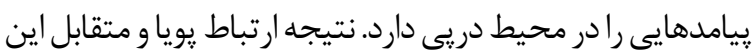
اجزا، عملكرد اكوييشن است [If]

عوامل مؤثر بر خواب سالمندان در يزوهشهاى متعدى مورى مورد

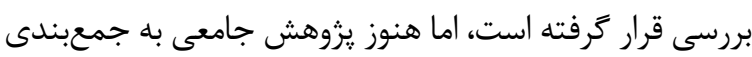

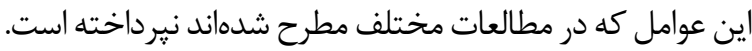

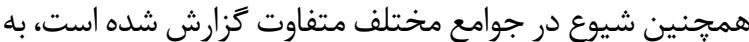

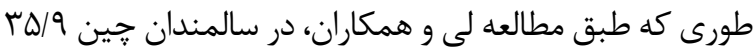

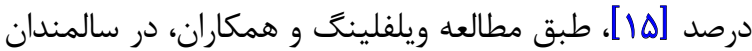

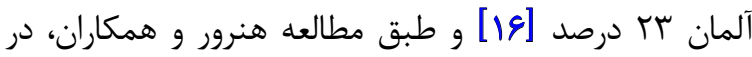

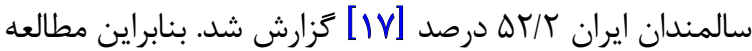

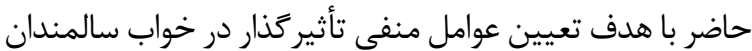

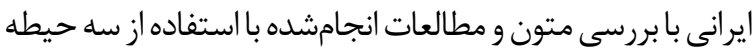
مطرح در مدل شخص، محيط و اكوييشن صورت كرفته است.

\section{Person-Environment-Occupation (PEO) model}

3. Person

4. Environment

5. Occupation

6.Occupational Therapy Practice Framework (OTPF)

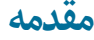

افزايش جمعيت سالمندان به علت كاهش مواليد، بهبود

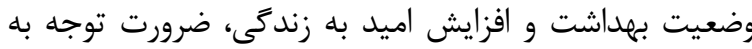

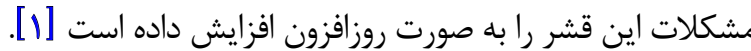

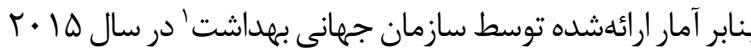

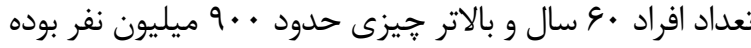

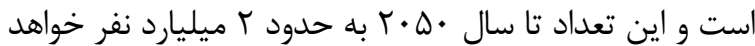

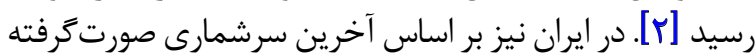

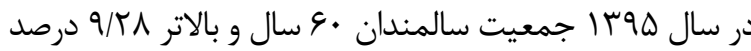

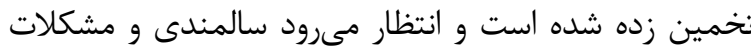

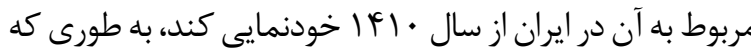

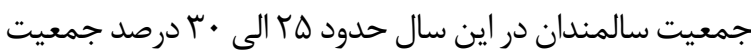

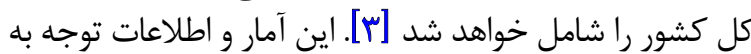

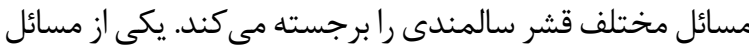

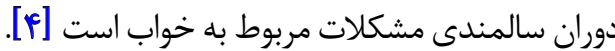

خواب و استراحت يك حالت فيزيولوزيك بيجيديده و يوياست

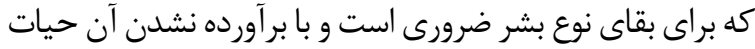

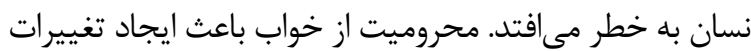

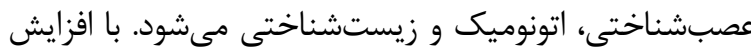

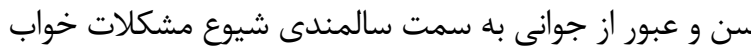

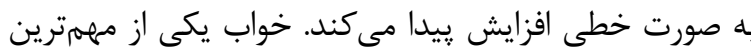

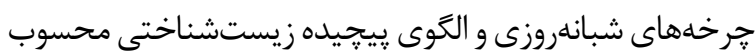

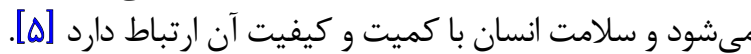

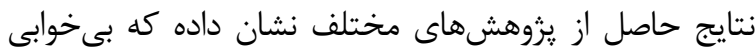

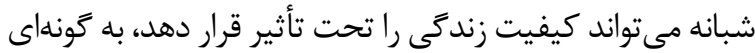

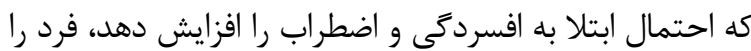

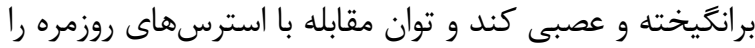

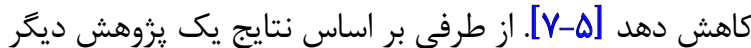

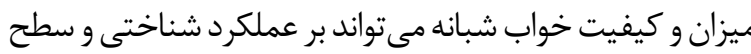

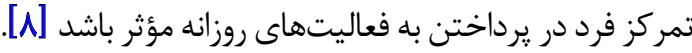
طبق بررسىهاى صورت كرفته شيوع بى خوابى و اختلال خواب

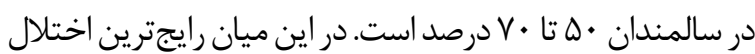

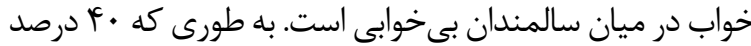

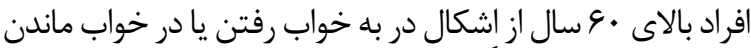

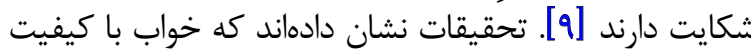

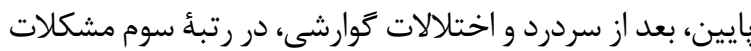

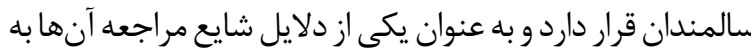

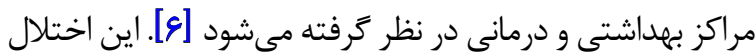

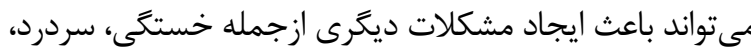

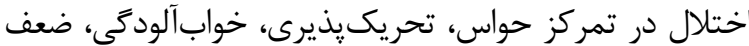

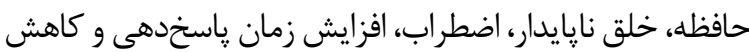

\section{World Health Organization (WHO)}




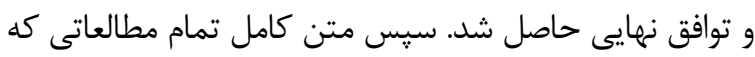

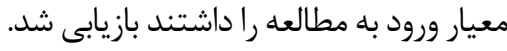
ارزيابى كيفيت مطالعات و استخر اج دادهها متن كامل مقالات منتخب يس از تأييد از نظر واجد شرايط

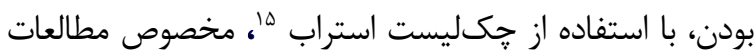

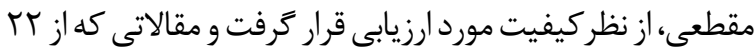

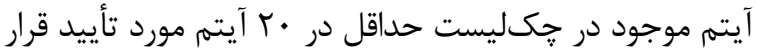

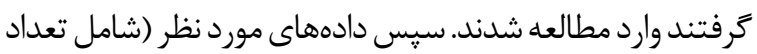

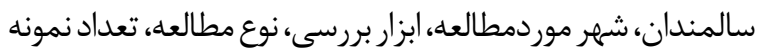

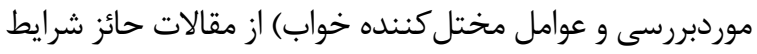

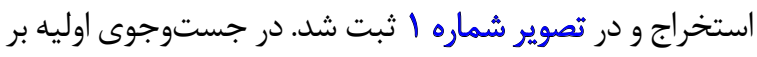

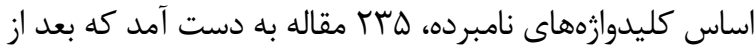

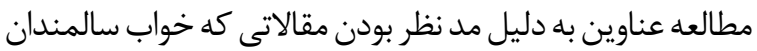

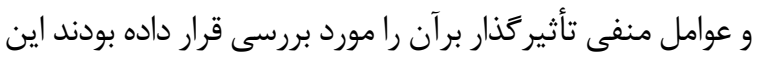

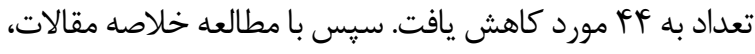

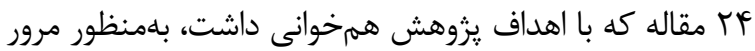

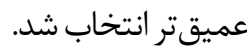

يافتهها

در اين مطالعه عوامل منفى مؤثر بر مشكلات خواب سالمندان

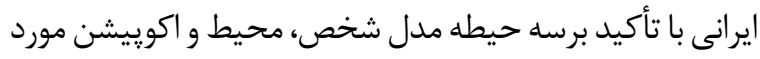

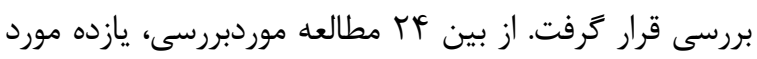

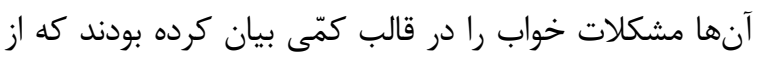

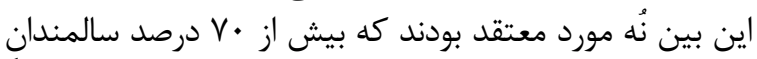

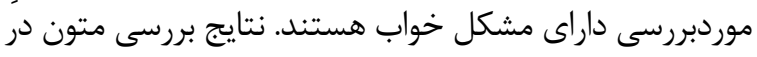

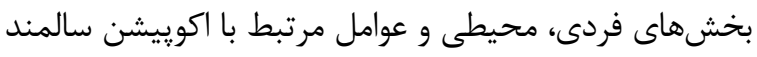

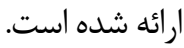

در هجده مقاله از مطالعات موردبررسى به عوامل فردى داى كه

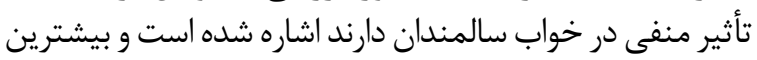
مقالات به مشكلات مرتبط با سلامتى فرديرداختند (تصوير

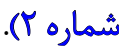

در يازده مقاله از مطالعات موردبررسى به عوامل محيطى كه دها

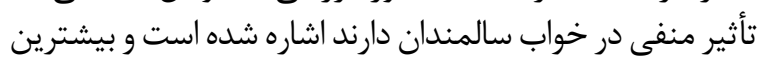

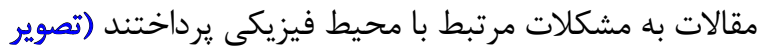

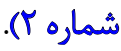

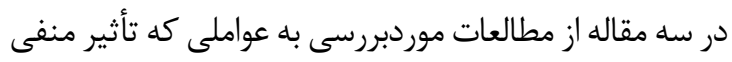

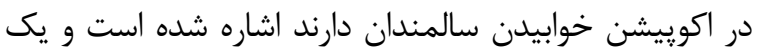

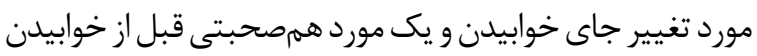

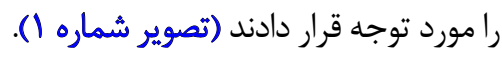

15. STROBE
اين مدل يكى از مدل هاى معمول و كاربردى در كاردرمانى است

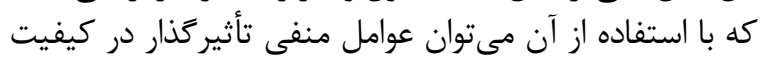

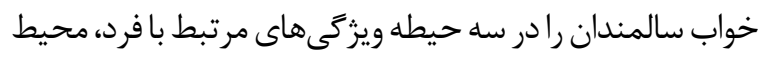
زندگى وى و عملكرد اكوييشن مورد بررسى قرار دار داد.

$$
\text { روش بررسى }
$$

استراترى جستوجو: در اين مطالعه مرورى نظاممند

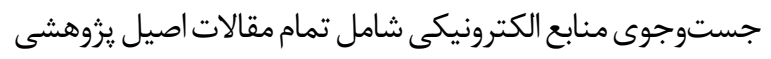

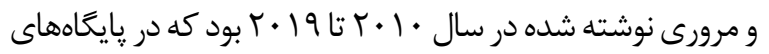

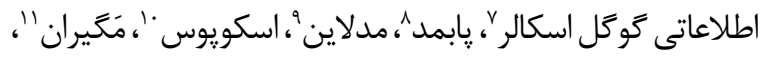

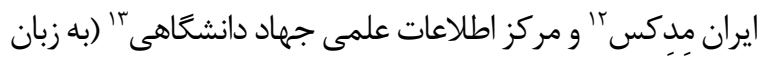

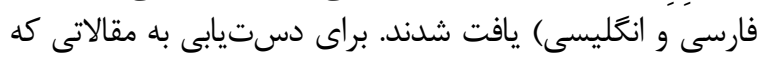

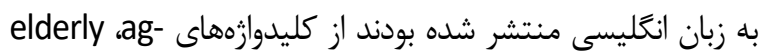
مقالتفار

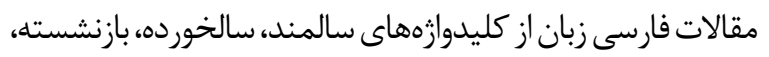

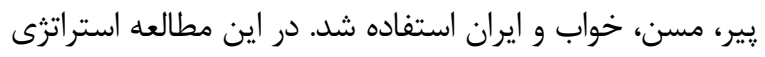

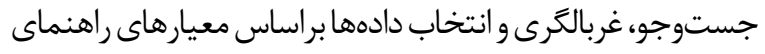

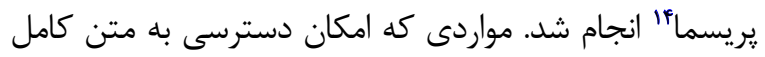
آنها وجود نداشت از مطالعه خارج شدند. معيار هاى ورود و خروج و انتخاب مطالعات ازئ آنجا كه هدف اين مطالعه مرورى، بررسى عوامل منفى

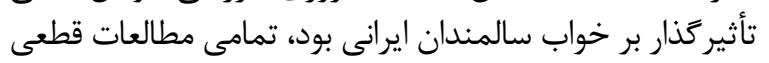

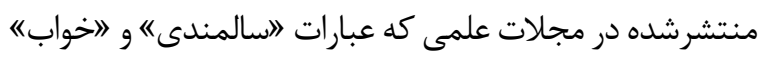

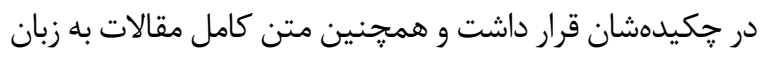

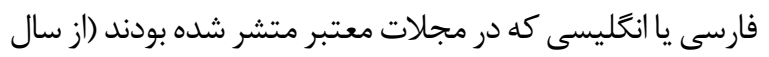

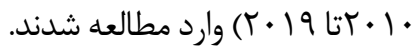

معيارهاى خروج عبارت بودند از: مطالعاتى كه مشكلات

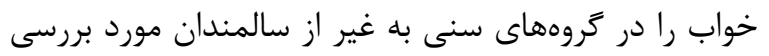

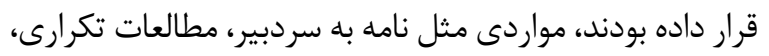

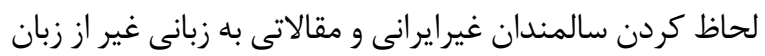
فارسى و انخليسى.

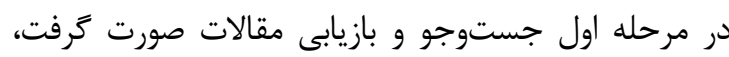

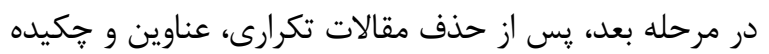

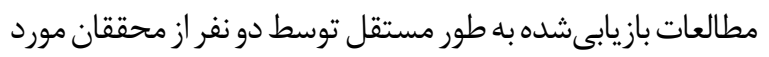

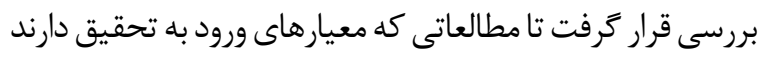

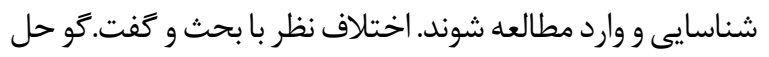

\section{Google Scholar \\ 8. PubMed \\ 9. Medline \\ 10. Scopus \\ 11. Magiran \\ 12. IranMedex \\ 13. SID \\ 14. PRISMA}


بيمارىهاى مزمن از عوامل منفى فردى تأثيرگذار بر خواب

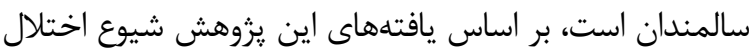

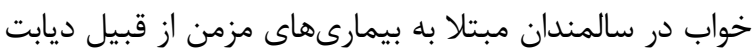

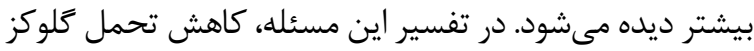

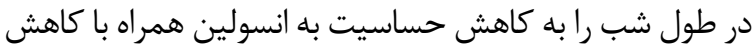

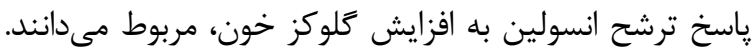

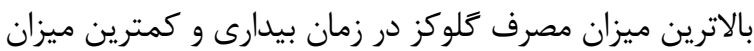

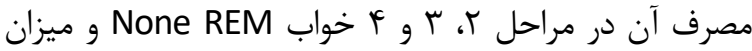

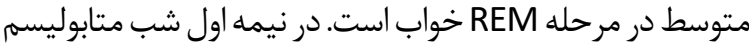

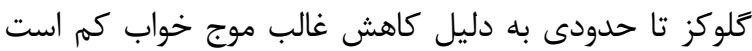

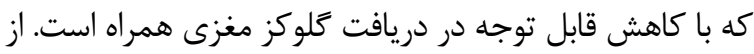

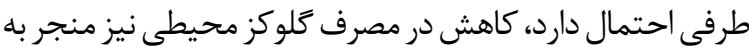

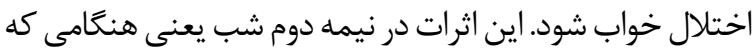

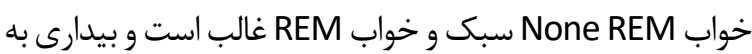
احتمال زياد رخ مىدهد، معكوس مىشود بر اساس جمعبندى مطالعات موردبررسى در اين يزوهش، زئنان

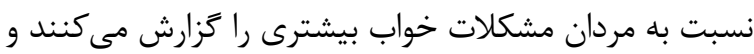

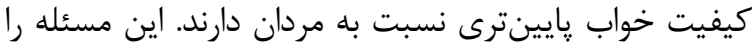

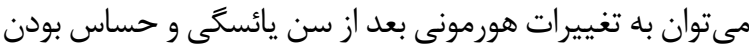

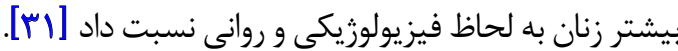

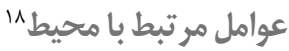

بر اساس يزوهشهاى صورت كرفته در زمينه خواب سالمندان

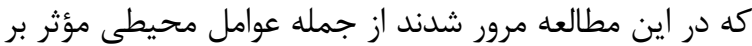

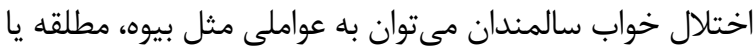

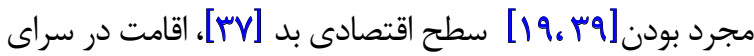

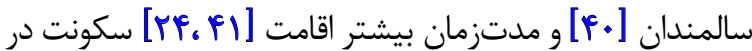

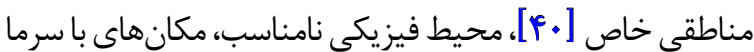

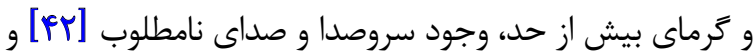

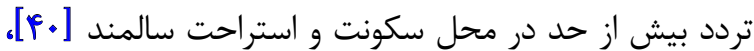

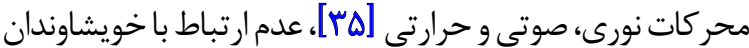

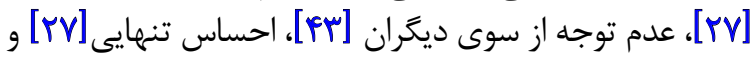

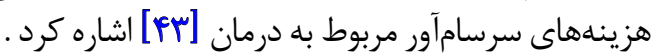

از جمله عوامل محيطى ايجادكننده مشكلات خواب، سكونت

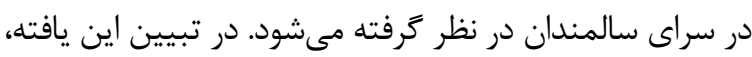

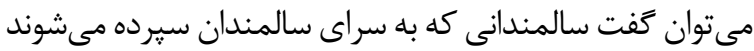

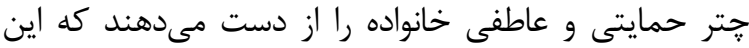

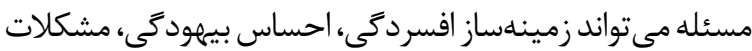

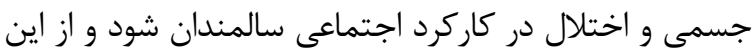

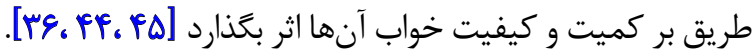

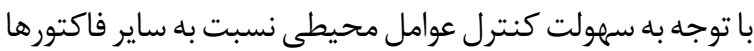

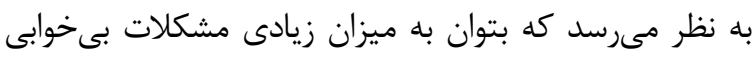

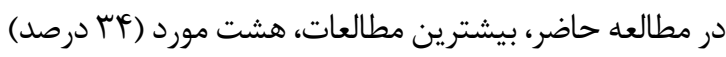

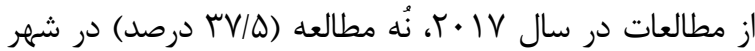

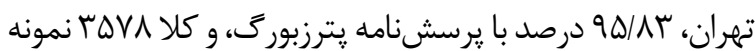

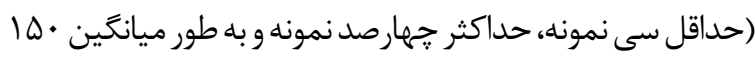

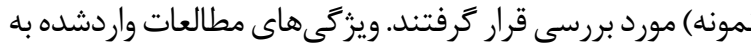

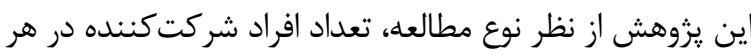

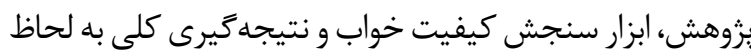

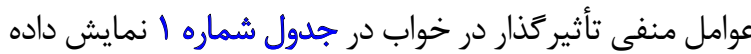

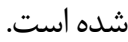
بحث نظر به اينكه در يزوهش حاضر با نكاه و فلسفه كاردرمانى

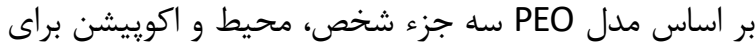

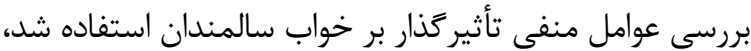

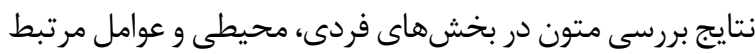
با اكوييشن خوابيدن ارائه شده است.

عوامل مرتبط با شخص

عواملى مثل افزايش هرجه بيشتر سن در سالمندان [1A]،

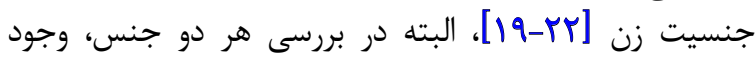
زمينههايى از بيمارى هاى روانى (براى زنان)؛ وجود إنى موانع و و مشكلات

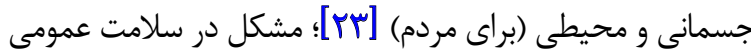

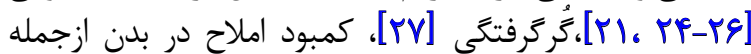

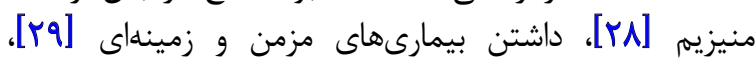

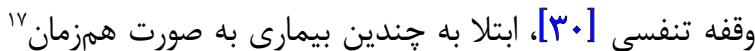

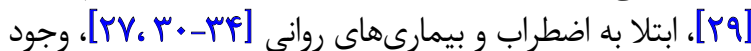

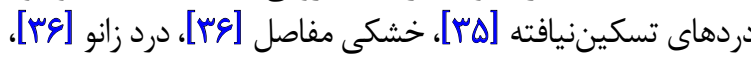

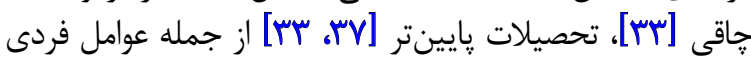
ايجادكننده مشكلات خواب در سالمندان به حساب ميى آيند. از عوامل فردى مى توان به افزايش سن در سالمندى اشاره كرد.

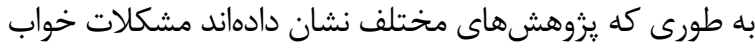

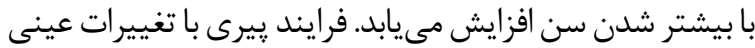

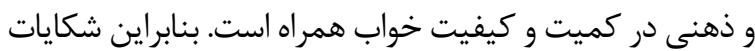

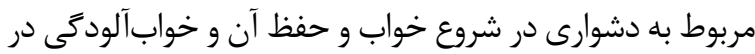

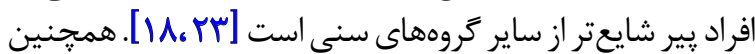

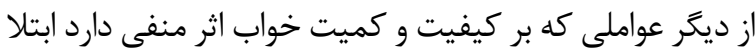

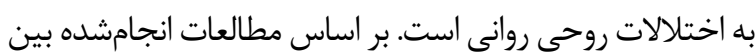

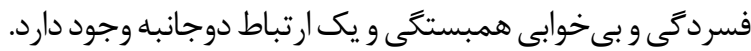

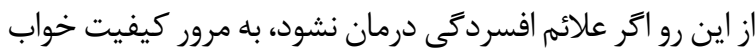

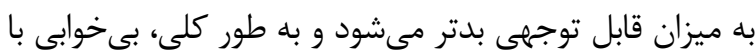

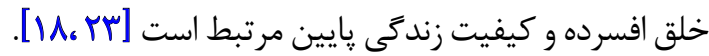

\section{Person}

17. Comorbidity 


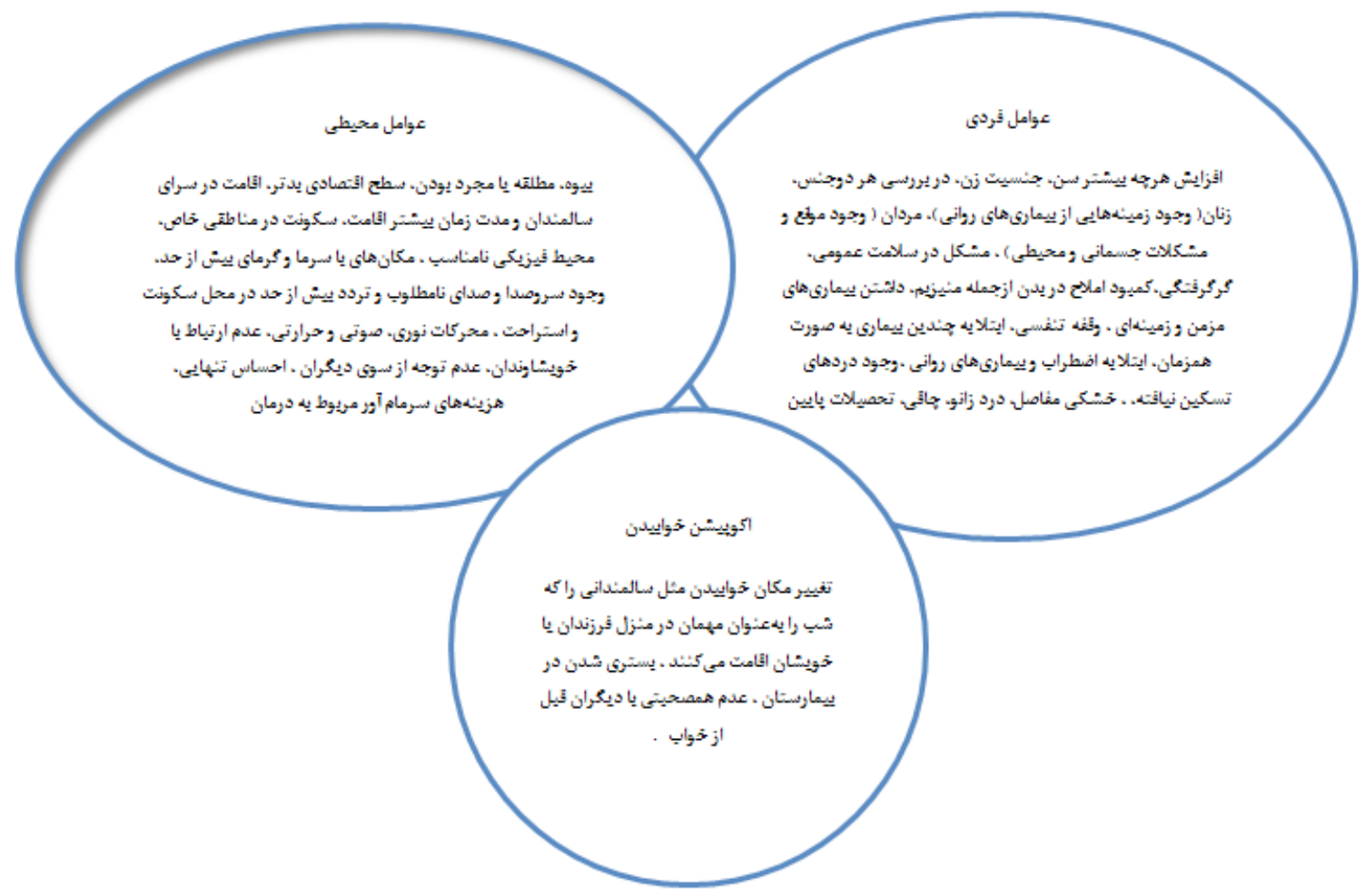

توانبخننى تصوير ا. عوامل مختل كنثده خواب سالمندان بر اساس مدل PEO (مدل فرد، محيط و اكوييشن)

در بررسى متون صورت گرفته مشخص شد كه سالمندان

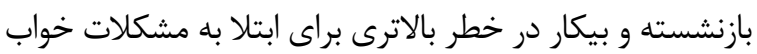

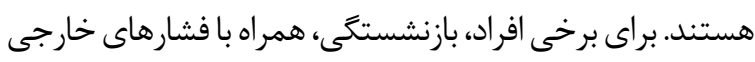

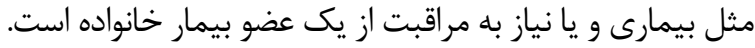

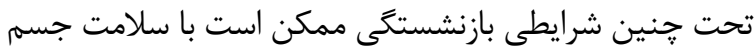

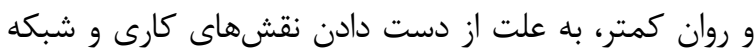

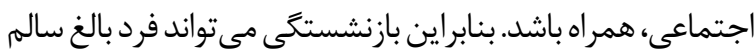

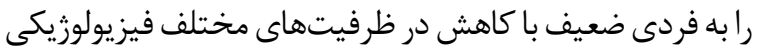

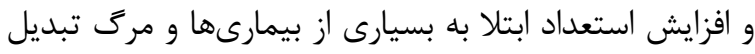

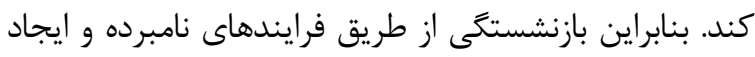

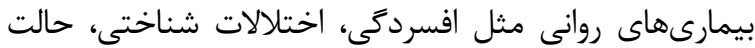

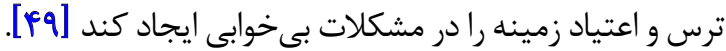

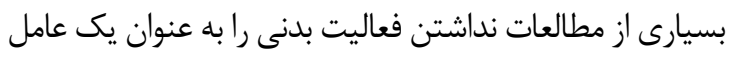

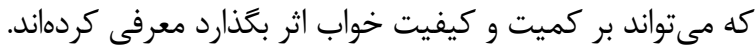

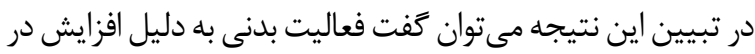

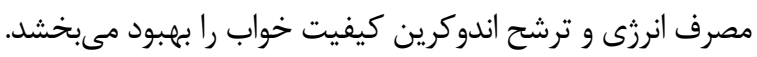

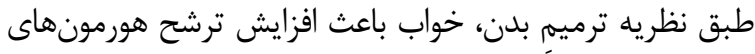

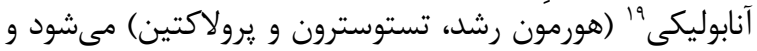

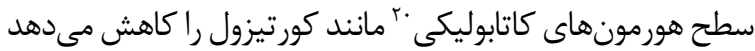

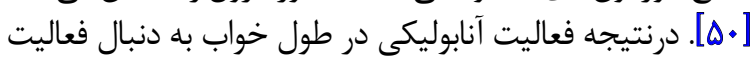

19. Anabolic hormone

20. Catabolic hormone
ناشى از محيط فيزيكى به دليل شرايط نامطلوبى مثل سرما و

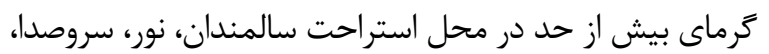

رختخواب نامناسب را اصلاح كرد [عبّ]. سالمندان متأهل نسبت به آن هايى كه مجرد، بيوه و يا يا مطلقه بودند

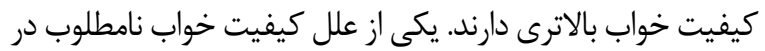

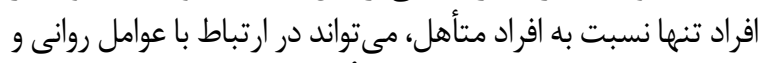

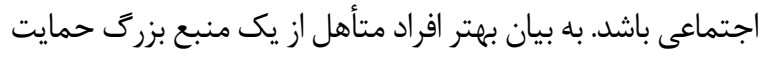

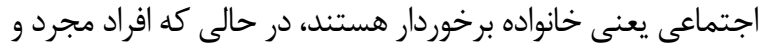

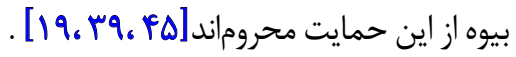
عوامل مرتبط با اكوييشن خُوابيدن

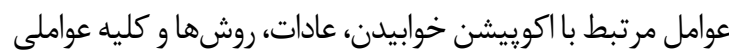

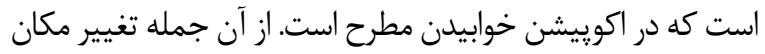

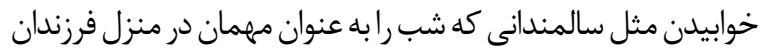

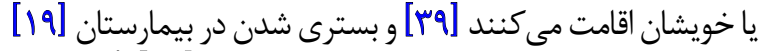

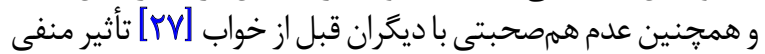

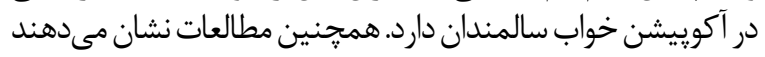

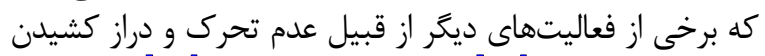

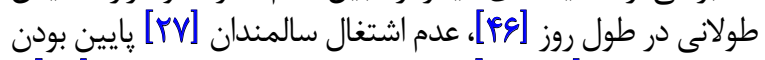

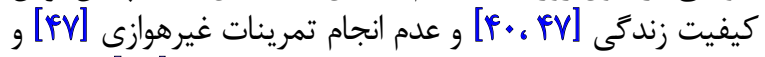

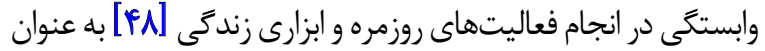

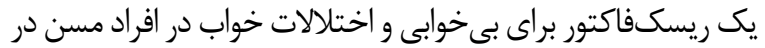
نظر گرفته مىشود. 


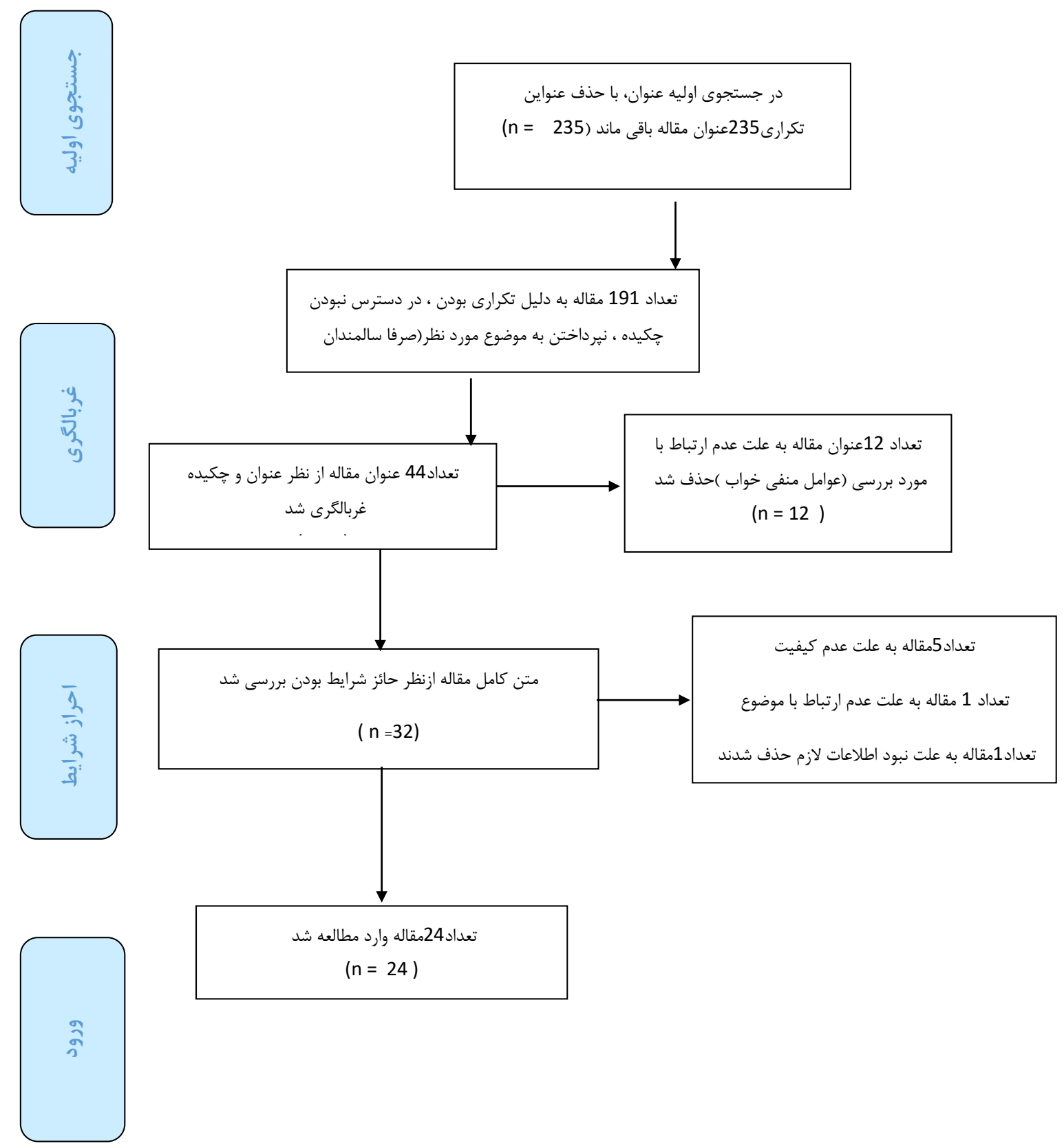

توانبخننى

تصوير r. مراحل انتخاب و ورود مطالعات در عوامل منفى تأثير كذار در خواب سالمندان ايرائى

در ساير مطالعات مرورى در دنيا، يِيرامون خواب سالمندان به

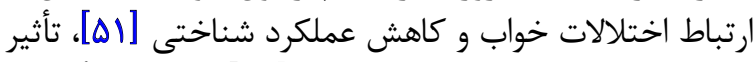

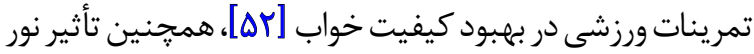
درخشان، رفتاردرمانى شناختى و تمرينات حركتئى بر بر اختيلابلات خواب سالمندان [بهان يرداخته شده است

$$
\text { نتيجحهيرى }
$$

در مطالعه عوامل منفى تأثير حذار در اختلالات خواب سالمندان

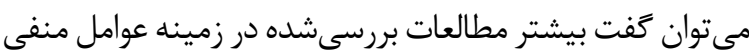
تأثير گذار بر خواب سالمندان، عوامل فردى مانند افزايش هر جهـ
كاتابوليكى در طول بيدارى اتفاق مى افتد و سنتز يروتئين در بيشتر

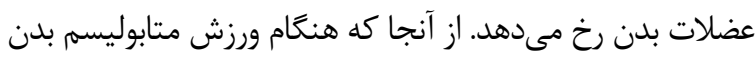

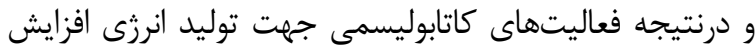

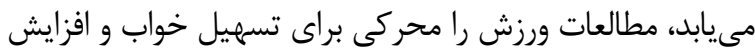

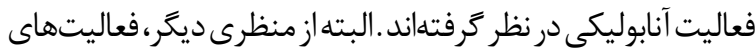

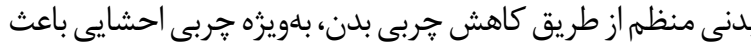

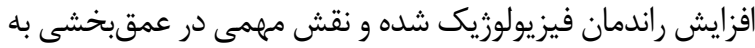

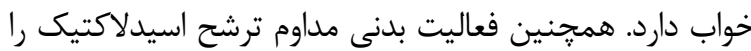

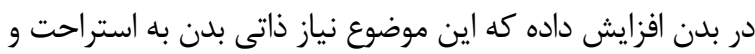

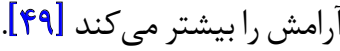


جدول ا.ويرّكىهاي مهم مطالعات بررسيشده

\begin{tabular}{|c|c|c|c|c|c|c|c|}
\hline حيطه مدل & عوامل منفي & ثتايج & ابزار & تعداد & نوع مطالعه & منيع & \\
\hline شخيط، & 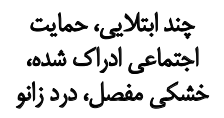 & 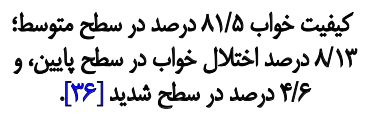 & ييتزبورى & مقيهم شهير الهواز & مطالعه & $\begin{array}{l}\text { هائي و همكاران } \\
\text { (T.19) }\end{array}$ & 1 \\
\hline هخيط، & كتترل نامطلوب قلامت روانون & 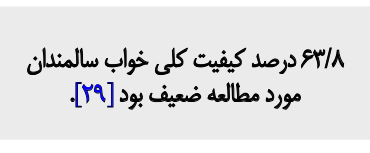 & يبيزيورى & 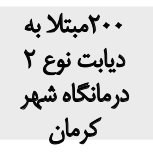 & هطالعه مقطعى & 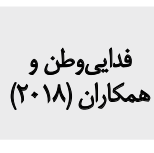 & $r$ \\
\hline هحيط & كاهش عملكرد توجه & 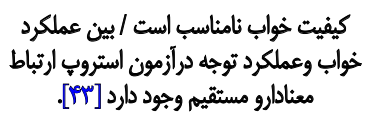 & ييتزبورك & 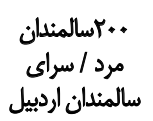 & |توصيفى | & 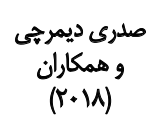 & $r$ \\
\hline شخيط، & 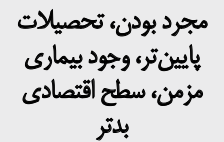 & كيفيت خواب سالمندان شهر يزّد در هVانرصد & ييتزبورى & سالمندان شيه & مقطعى تحليلى & همكاران (Vيرزائ و (r) & $f$ \\
\hline
\end{tabular}

\begin{tabular}{|c|c|c|c|c|c|c|c|}
\hline اكويشيط & بسترى شدن دربه & 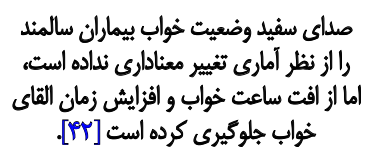 & يبيتزبورى & 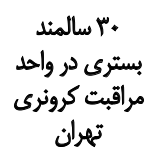 & نيمهتجربيى & 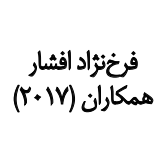 & $\Delta$ \\
\hline هخيط & 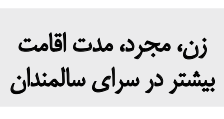 & 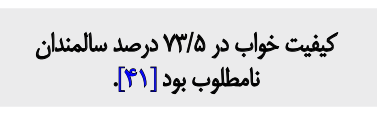 & ييتزبورى & سراي شيهر سالمندان & مطالعه مقطعى & همكاران (r) & 8 \\
\hline شخص & وقفه تثفسى & 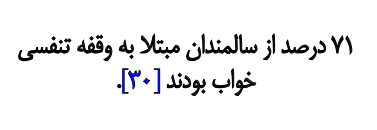 & 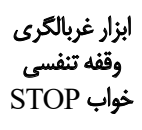 & 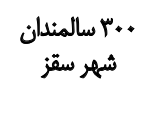 & مقطعى تحليلى & 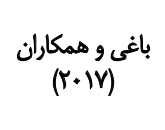 & $\checkmark$ \\
\hline هحيط & 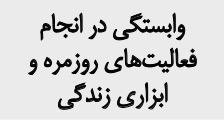 & 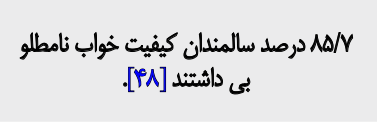 & ييتزبورى & 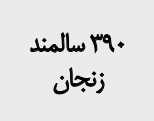 & ثشاهدماى & 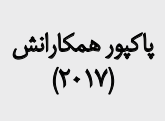 & $\Lambda$ \\
\hline شخصي، & 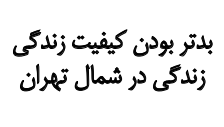 & 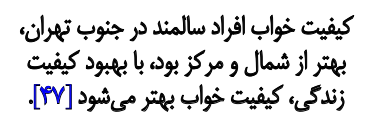 & ييتزبورى & سراى تهران & توصيفى & همكاران يُؤوه و.|V) & 9 \\
\hline شخمصن، & علم ورازش كردن & 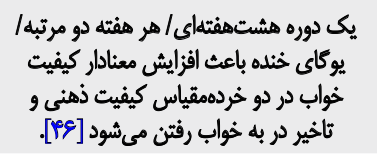 & ييثزبورى & باركينسون & 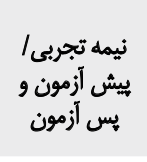 & همكاران (Vماريان و (r) & 1. \\
\hline شُحْص & تشويش و اضطراب & 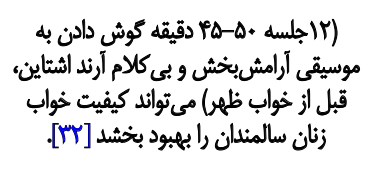 & يجيتزبورى & 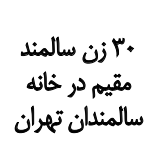 & 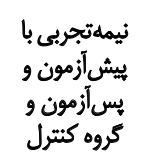 & همكاران (N (T) & 11 \\
\hline شخيط، & 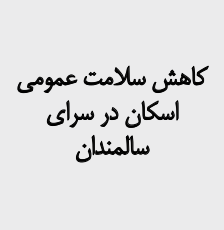 & 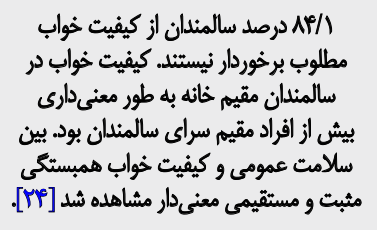 & ي ييتزبورى & • شهر لار & مطالعه مقطعىى & همكاران (19 (r) & $\pi$ \\
\hline هحيط & احساس تنهايى & 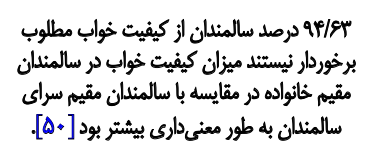 & ييتزبورى & 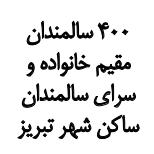 & مقطعى تحليلى & 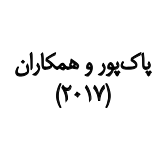 & זו \\
\hline
\end{tabular}




\begin{tabular}{|c|c|c|c|c|c|c|c|}
\hline حيطه مدل & عوامل مثفى & نتايج & ابزار & تعداد & نوع مطالعه & منيع & \\
\hline شخص & زن، سطح فعاليث بلدنى يإيين & 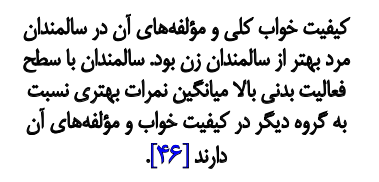 & ييثزيورى & 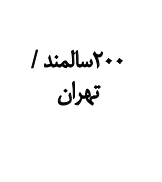 & علنى مثقايسهاى & $\begin{array}{l}\text { كهندل و همكاران } \\
\text { (r.10) }\end{array}$ & if \\
\hline شخص،، محيط & عدم تحرى بدنى و ورزظش & 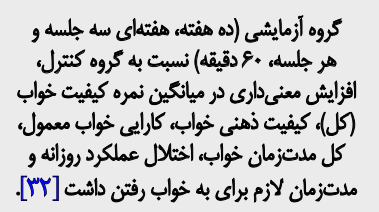 & بيتزبورى & 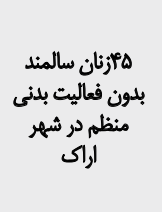 & 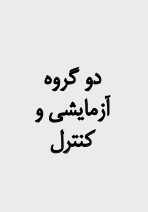 & 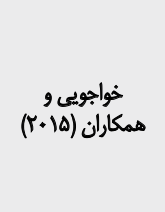 & 10 \\
\hline شُخص،، محيط & 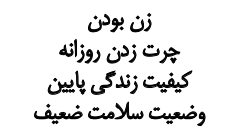 & 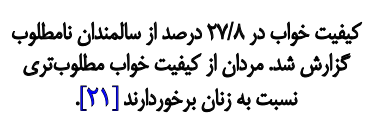 & ييتزبوزى & 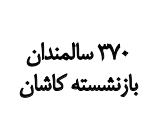 & همطعمى تعليلى & $\begin{array}{c}\text { صفاو همكارانش } \\
\text { (r.15) }\end{array}$ & is \\
\hline شخص، محيط & نا اميدى، استرس & معنادرمانى تأثير معثادارى بر كيفيت خواب & ييتزبورى & 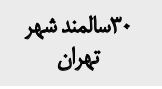 & متطعى تحليلى & احمريان (هان فاميل & iv \\
\hline هحيط & عدم انجام تمرينات & 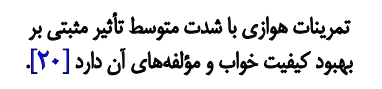 & ييتزبورى & "هt سالمند مرد & $\begin{array}{c}\text { هقطعى (آزمايش } \\
\text { وكتثرل) }\end{array}$ & $\begin{array}{c}\text { اكبي كامرانى } \\
(T \cdot 1 A)\end{array}$ & M \\
\hline شخصص & افسردىى، جاقى & 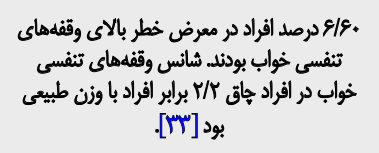 & يرسشنامه برلين & افسرده شهرستان & هتطعى تحليلى & $\begin{array}{c}\text { فرزاده و همكاران } \\
\text { و (r.15) }\end{array}$ & 19 \\
\hline شخص & 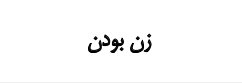 & 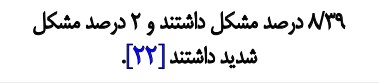 & ييتزبورى & كرمائشاه & توصيفى مقطعى & $\begin{array}{l}\text { شيخم و همكاران } \\
(r \cdot 14)\end{array}$ & $r$. \\
\hline شخص،، محيط & 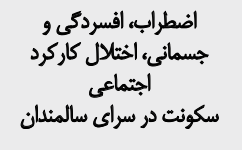 & 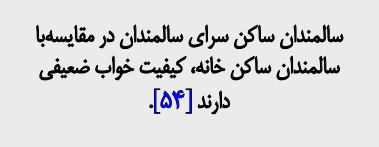 & ييتزبورى & 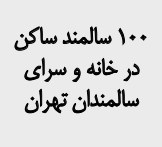 & هقطعى تحليلى & 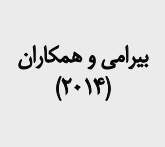 & ri \\
\hline شخصن، محيط & 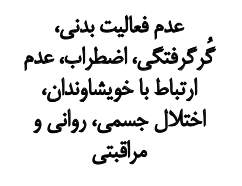 & 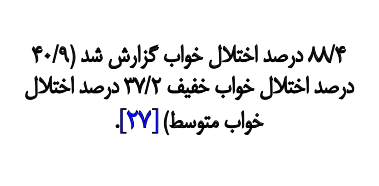 & 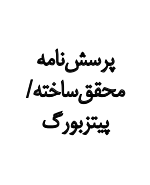 & كمريزك تهران & هقطعى & 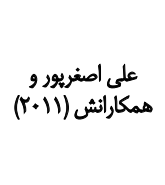 & $r$ \\
\hline شخص، محيط & 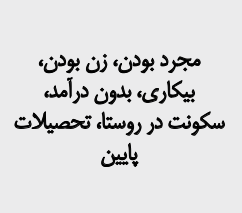 & 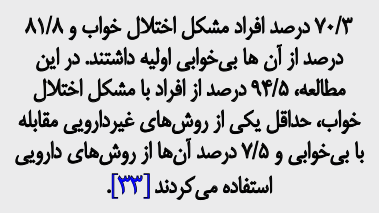 & 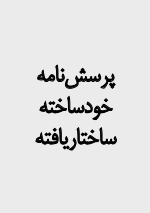 & 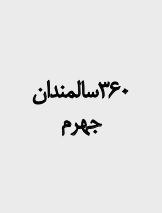 & مطالعه مقطعى & 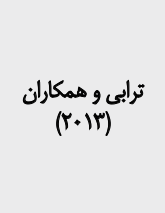 & r \\
\hline
\end{tabular}

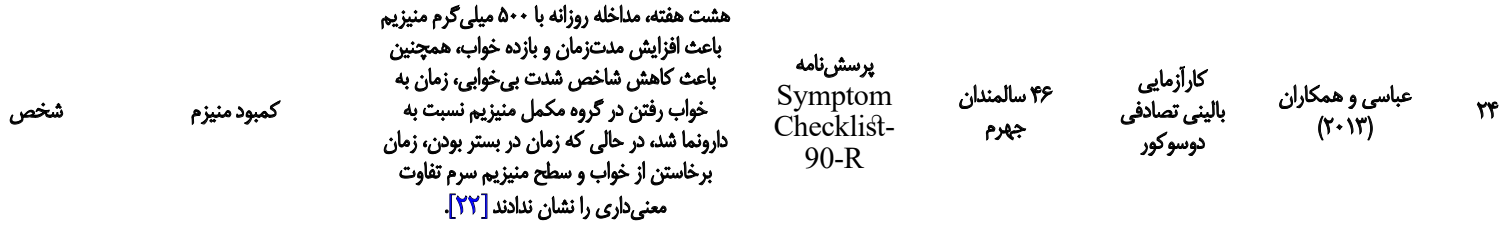




$$
\text { بيشتر سن، مؤنث بودن، ابتلا به بيمارىهاى مزمن و زمينهاى، تعارض منافع }
$$

بنا به اظهار نويسندَان در اين مقاله هيجَّونه تعارض منافعى

$$
\text { تشود ندارد. }
$$

برخود لازم مى دانيم از اساتيد گروه كاردرمانى دانشخاه علوم

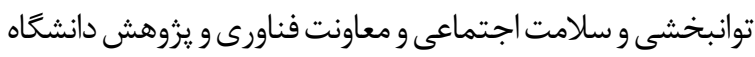
علوميزشكى همدان كمال تشكر و قدردانى را داشته باشيه.

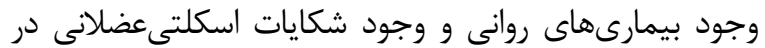

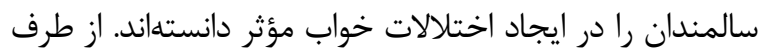

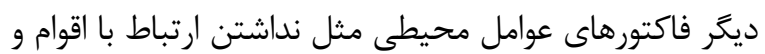

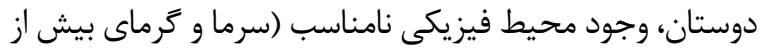

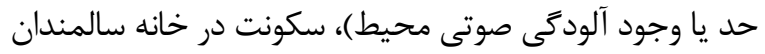

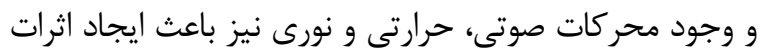

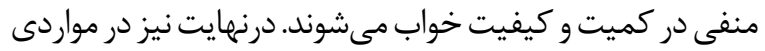

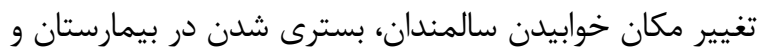

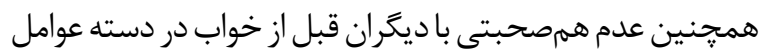

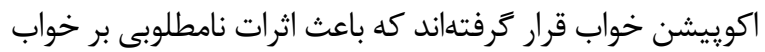

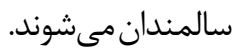

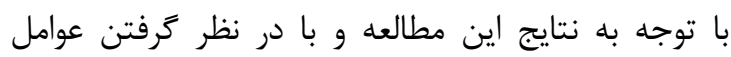

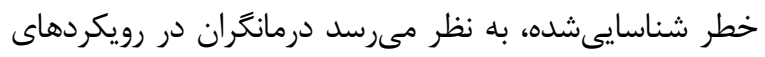

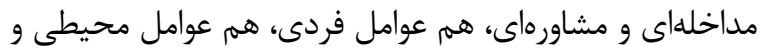

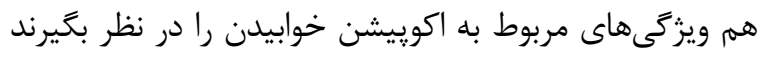

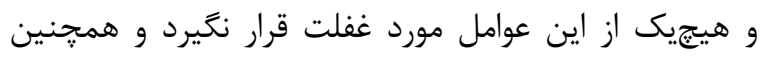

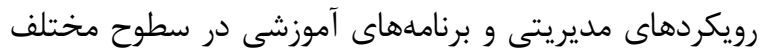
سياست كذارى شود. مديتي

از جمله محدوديتهاى اين يزوهش دسترسى نداشتن به مته متن

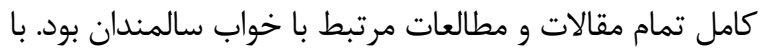

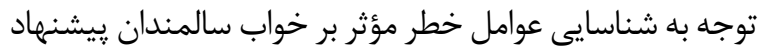

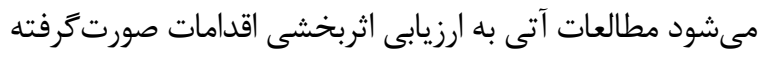

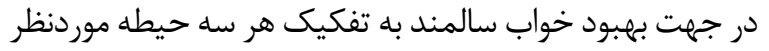
يعنى شخص، محيط و اكوييشن بيردازند.

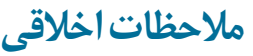

$$
\text { ييروى از اصول اخلاق يخوهش }
$$

اين مقاله از نوع مرورى است و نمونه انسانى يا حيوانى نداشته است. مطالعه حاضر از نوع تحقيقات توصيفى با كد اخلاق إن اندان

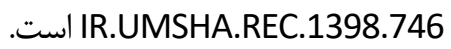

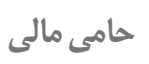

اين مقاله منتج از طرح تحقيقاتى دانشكاه علوميزشكى همدان

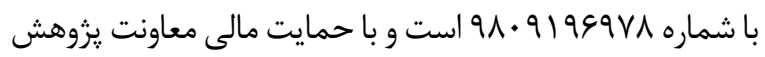

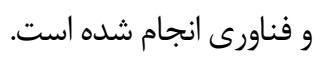

$$
\text { مشاركت نويسندًان }
$$

تمام نويسندگًان در طراحى، اجرا و نغارش همه بخشهاى

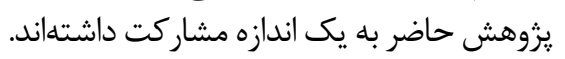




\section{Referencs}

[1] Reimer MA, Flemons WW. Quality of life in sleep disorders. Sleep Medicine Reviews. 2003; 7(4):335-49. [DOI:10.1053/ smrv.2001.0220]

[2] World Health Organization. WHO: Number of people over 60 years set to double by 2050; major societal changes required [Internet]. 2015 [Updated 2015 September 30]. Available from: https://www.who.int/news/item/30-09-2015-who-numberof-people-over-60-years-set-to-double-by-2050-major-societalchanges-required

[3] Hardin KA. Sleep in the ICU: Potential mechanisms and clinical implications. Chest. 2009; 136(1):284-94. [DOI:10.1378/ chest.08-1546]

[4] Park JH, Yoo MS, Bae SH. Prevalence and predictors of poor sleep quality in Korean older adults. International Journal of Nursing Practice. 2013; 19(2):116-23. [DOI:10.1111/ijn.12047]

[5] BehPajooh A, Soleymani S. [The relationship between sleep quality and depression in older people living in 3 districts of Tehran, Iran (Persian)]. Salmand: Iranian Journal of Ageing. 2016; 11(1):72-9. [DOI:10.21859/sija-110172]

[6] Cotroneo A, Gareri P, Lacava R, Cabodi S. Use of zolpidem in over 75-year-old patients with sleep disorders and comorbidities. Archives of Gerontology and Geriatrics. 2004; 38(Suppl):93-6. [DOI:10.1016/j.archger.2004.04.015]

[7] LeBlanc M, Beaulieu-Bonneau S, Mérette Ch, Savard J, Ivers H, Morin CM. Psychological and health-related quality of life factors associated with insomnia in a population-based sample. Journal of Psychosomatic Research. 2007; 63(2):157-66. [DOI:10.1016/j. jpsychores.2007.03.004]

[8] e Silva JAC. Sleep disorders in psychiatry. Metabolism. 2006; 55(2):S40-4. [DOI:10.1016/j.metabol.2006.07.012]

[9] Grewal RG, Doghramji K. Epidemiology of insomnia. In: Attarian $\mathrm{H}$, editor. Clinical handbook of insomnia. Current Clinical Neurology. Cham: Springer; 2017. pp. 13-25. [DOI:10.1007/9783-319-41400-3_2]

[10] Harvey AG, Buysse DJ. Treating sleep problems: A transdiagnostic approach. New York: Guilford Publications; 2017. https://books.google.com/books?id=gaMzDwAAQBAJ\&dq

[11] Prinz PN, Vitiello MV, Raskind MA, Thorpy MJ. Sleep disorders and aging. The New England Journal of Medicine. 1990; 323(8):520-6. [DOI:10.1056/NEJM199008233230805]

[12] Riemann D, Nissen Ch, Palagini L, Otte A, Perlis ML, Spiegelhalder K. The neurobiology, investigation, and treatment of chronic insomnia. The Lancet Neurology. 2015; 14(5):547-58. [DOI:10.1016/S1474-4422(15)00021-6]

[13] Knis Matthews L, Mulry CM, Richard L. Matthews model of clinical reasoning: A systematic approach to conceptualize evaluation and intervention. Occupational Therapy in Mental Health. 2017; 33(4):360-73. [DOI:10.1080/0164212X.2017.1303658]

[14] Khazaeli Kh, Rassafiani M. [Human occupation: A primary attempt to develop a comprehensive definition (Persian)]. Journal of Research in Rehabilitation Sciences. 2012; 7(5):723-31. http:// jrrs.mui.ac.ir/index.php/jrrs/article/view/331
[15] Lu L, Wang SB, Rao W, Zhang Q, Ungvari GS, Ng CH, et al. The prevalence of sleep disturbances and sleep quality in older Chinese adults: A comprehensive meta-analysis. Behavioral Sleep Medicine. 2019; 17(6):683-97. [DOI:10.1080/15402002. 2018.1469492]

[16] Wilfling D, Dichter MN, Trutschel D, Köpke S. Prevalence of sleep disturbances in German nursing home residents with dementia: A multicenter cross-sectional study. Journal of Alzheimer's Disease. 2019; 69(1):227-36. [DOI:10.3233/JAD-180784]

[17] Honarvar B, Bagheri Lankarani K, Azadegan M, Khaksar E, Jafari F, Rahmani Fard T. The prevalence and predictors of sleep disturbance in the elderly: A population-based study in Shiraz, Iran. Shiraz E-Medical Journal. 2019; 20(11):e88349. [DOI:10.5812/semj.88349]

[18] Morphy H, Dunn KM, Lewis M, Boardman HF, Croft PR. Epidemiology of insomnia: A longitudinal study in a UK population. Sleep. 2007; 30(3):274-80. [PMID]

[19] Aliasquarpoor M, Eybpoosh S. [The quality of life of elderly nursing home residents and its relationship with different factors (Persian)]. Iran Journal of Nursing. 2012; 25(75):60-70. http://ijn.iums.ac.ir/article-1-1256-en.html

[20] Kohandel M, Sanatkaran A, Alikaram A. [The comparison of cognition performance and sleep quality in older adults with different physical activity levels (Persian)]. Strategic Studies on Youth and Sports. 2015; 14(29):185-200. https://www.sid.ir/ $\mathrm{fa} /$ journal $/$ ViewPaper.aspx?id $=321670$

[21] Safa A, Adib Hajbaghery M, Moradi T. [Quality of sleep and its related factors in elderly and retired teachers of Kashan (2015) (Persian)]. Avicenna Journal of Nursing and Midwifery Care. 2015; 23(4):29-38. http://nmj.umsha.ac.ir/article-1-1398-en. html

[22] Sheikhy L, Karami Mattin B, Chupani J, Hookari S, Fallah B. [Evaluation the status of sleep quality in elderly people in Kermanshah city (Persian)]. Rehabilitation Medicine. 2015; 3(4):818. http://medrehab.sbmu.ac.ir/article_1100068.html

[23] Malakouti SK, Foroughan M, Nojomi M, Ghalebandi MF, Zandi T. Sleep patterns, sleep disturbances and sleepiness in retired Iranian elders. International Journal of Geriatric Psychiatry. 2009; 24(11):1201-8. [DOI:10.1002/gps.2246]

[24] Maghsoudi A, Dindarloo S, Jamali T, Ghaed S, Rastgoo Z, Hassanipour Azgomi S. [Comparison of sleep quality and general health in elderly individuals living in their houses and nursing homes (Persian)]. Sadra Medical Journal. 2016; 4(3):161-72. https://smsj.sums.ac.ir/article_44092.html

[25] Beyrami M, Alizadeh Goradel J, Ansarhosein S, Ghahraman Moharrampour N. [Comparing sleep quality and general health among the elderly living at home and at nursing home (Persian)]. Salmand: Iranian Journal of Ageing. 2014; 8(4):47-55. http://salmandj.uswr.ac.ir/article-1-525-en.html

[26] Foroughan M, Habibi Ghahfarrokhi Sh, Malakouti SK. [Daytime sleepiness: A factor correlated with mental health of older people (Persian)]. Salmand: Iranian Journal of Ageing. 2012; 7(3):12-20. http://salmandj.uswr.ac.ir/article-1-517-en.html 
[27] Aliasgharpoor M, Eybpoosh S. [Quality of sleep and its correlating factors in residents of Kahrizak nursing home (Persian)]. Nursing and Midwifery Journal. 2011; 9(5):374-83. http://unmf. umsu.ac.ir/article-1-611-en.html

[28] Abbasi B, Kimiagar M, Shahidi Sh, Shirazi M, Sadeghniiat K, Hedayati M, et al. [Effect of magnesium supplementation on indices of psychological disorders in insomniac elderly subjects: A double-blind randomized clinical trial (Persian)]. Journal of Ardabil University of Medical Sciences. 2013; 13(2):206-19. http:// jarums.arums.ac.ir/article-1-118-fa.html

[29] Fadayevatan R, Bahrami M, Mohamadzadeh M, Borhaninejad V. [Relationship of sleep quality with mental health and blood sugar control in elderly people with diabetes mellitus (Persian)]. Salmand: Iranian Journal of Ageing. 2020; 14(4):380-91. [DOI:10.32598/sija.13.10.120]

[30] Baghi V, Shahbazi Hesabi P, Mohammadi H, Ghanei Gheshlagh R. [The relationship between sleep apnea and quality of life of the elderly in Saqez-Iran (Persian)]. Journal of Gerontology. 2017; 2(2):51-7. [DOI:10.29252/joge.2.2.51]

[31] Baglioni Ch, Battagliese G, Feige B, Spiegelhalder K, Nissen $\mathrm{Ch}$, Voderholzer $\mathrm{U}$, et al. Insomnia as a predictor of depression: A meta-analytic evaluation of longitudinal epidemiological studies. Journal of Affective Disorders. 2011; 135(1-3):10-9. [DOI:10.1016/j.jad.2011.01.011]

[32] Khodabakhshi-Koolaee A, Zahmatkesh M, Barzeghar Khezri R. [The effect of relaxation and instrumental music by Arnd Stein on quality of sleep and happiness among ageing women (Persian)]. Journal of Torbat Heydariyeh University of Medical Sciences. 2018; 5(4):46-53. http://jms.thums.ac.ir/article-1-466-en.html

[33] Farajzadeh M, Hosseini M, Mohtashami J, Chaibakhsh S, Zaghari Tafreshi M, Hajnasiri H. [Studying relationship between body mass index and obstructive sleep apnea in depressed elderly patients in Saqqez city in 2014 (Persian)]. Medical Sciences Journal of Islamic Azad University, Tehran Medical Branch. 2016; 26(2):116-22. http://tmuj.iautmu.ac.ir/article-1-1098-en.html

[34] Ahmarian FSF, Khodabakhshi Koolaee A, Falsafinejad MR. [The effects of group logo-therapy on life expectancy and sleep quality in elderlies of boarding center of Tehran city (Persian)]. Journal of Pizhūhish dar dīn va Salāmat. 2015; 1(3):11-8. https:// journals.sbmu.ac.ir/en-jrrh/article/view/12009

[35] Rejeh N, Heravi-Karimooi M, Foroughan M. [An exploration into the lived experiences of the hospitalized older women of sleep phenomenon and its disturbance: A qualitative study (Persian)]. Daneshvar Medicine. 2010; 17(68):19-30. https://www.sid. ir $/$ fa/journal $/$ ViewPaper.aspx?id=118439

[36] Papi Sh, Karimi Z, Ghaed Amini Harooni GR, Nazarpour A, Shahry P. [Determining the prevalence of sleep disorder and its predictors among elderly residents of nursing homes of Ahvaz city in 2017 (Persian)]. Salmand: Iranian Journal of Ageing. 2019; 13(5):576-87. [DOI:10.32598/SIJA.13.Special-Issue.576]

[37] Mirzaei M, Gholamrezaei E, Bidaki R, Fallahzadeh H, Ravaei J. [Quality of sleep and methods of management of sleep disorders in elderly of Yazd city in 2016 (Persian)]. Journal of Shahid Sadoughi University of Medical Sciences. 2017; 25(6):467-75. http:// jssu.ssu.ac.ir/article-1-4233-en.html
[38] Johnson EO, Roth T, Breslau N. The association of insomnia with anxiety disorders and depression: Exploration of the direction of risk. Journal of Psychiatric Research. 2006; 40(8):700-8. [DOI:10.1016/j.jpsychires.2006.07.008]

[39] Borji M, Jahani S, Shiri P, Azami M. [Assessing the status of sleep quality in elderly city of Ilam in 2015 (Persian)]. Journal of Geriatric Nursing. 2016; 2(3):44-53. [DOI:10.21859/ign.2.3.44]

[40] Torabi S, Shahriari L, Zahedi R, Rahmanian S, Rahmanian K. [A survey the prevalence of sleep disorders and their management in the elderly in Jahrom city, 2008 (Persian)]. Journal of Jahrom University of Medical Sciences. 2012; 10(4):35-41. [DOI:10.29252/jmj.10.4.35]

[41] Bahrami M, Dehdashti AR, Karami M. [A survey on sleep quality in elderly people living in a nursing home in Damghan city in 2017: A short report (Persian)]. Journal of Rafsanjan University of Medical Sciences. 2017; 16(6):581-90. http://journal.rums.ac.ir/article1-3779-en.html

[42] Farokhnezhad Afshar P, Zahednezhad H, Ajri Khamesloo M, Ghanei Gheshlagh R, Fathi R. [Effect of white noise on the sleep of elderly patients hospitalized in coronary care units (Persian)]. Salmand: Iranian Journal of Ageing. 2016; 11(1):44-51. [DOI:10.21859/sija110144]

[43] Sadri Damirchi E, Akbari T, Mojarad A, Behbuei S. [The role of stroop performance in predicting sleep quality and quality of life in the elderly (Persian)]. Salmand: Iranian Journal of Ageing. 2019; 13(5):564-75. [DOI:10.32598/SIJA.13.Special-Issue.564]

[44] Winningham RG, Pike NL. A cognitive intervention to enhance institutionalized older adults' social support networks and decrease loneliness. Aging \& Mental Health. 2007; 11(6):716-21. [DOI:10.1080/13607860701366228]

[45] Kang YS, Kim ES, Gu MO, Eun Y. [A study on the health status and the needs of health-related services of female elderly in an urban-rural combined city (Korean)]. Journal of Korean Public Health Nursing. 2003; 17(1):47-57. https://www.koreascience.or.kr/article/ JAKO200302612928994.page

[46] Memarian A, Sanatkaran A, Bahari SM. The effect of laughter yoga exercises on anxiety and sleep quality in patients suffering from Parkinson's disease. Biomedical Research and Therapy. 2017; 4(7):146379. [DOI:10.15419/bmrat.v4i07.200]

[47] Beh-Pajooh A, Solimani S. [The relationship between quality of sleep and the quality of life of the elderly in three districts of Tehran (Persian)]. Aging Psychology. 2017; 3(2):107-14. https://jap.razi. ac.ir/article_747.html

[48] Pakpour V, Moqaddam M, Hosseiny RS, Salimi S. Quality of sleep and daily activity of the elderly in Zanjan. Journal of Research Development in Nursing and Midwifery. 2016; 13(1):62-8. [DOI:10.18869/ acadpub.jgbfnm.13.1.62]

[49] Amini A, Shirvani H, Bazgir B. [Comparison of sleep quality in active and non-active military retirement and its relationship with mental health (Persian)]. Journal of Military Medicine. 2020; 22(3):252-63. [DOI:10.30491/JMM.22.3.252]

[50] Pakpour V, Zamanzadeh V, Salimi S, Farsiv A, Moghbeli G, Soheili A. [The relationship between loneness and sleep quality in older adults In Tabriz (Persian)]. Nursing and Midwifery Journal. 2017; 14(11):906-17. http://unmf.umsu.ac.ir/article-1-3060-en.html 
[51] Lo JC, Groeger JA, Cheng GH, Dijk DJ, Chee MWL. Self-reported sleep duration and cognitive performance in older adults: A systematic review and meta-analysis. Sleep Medicine. 2016; 17:87-98. [DOI:10.1016/j.sleep.2015.08.021]

[52] Yang PY, Ho KH, Chen HC, Chien MY. Exercise training improves sleep quality in middle-aged and older adults with sleep problems: A systematic review. Journal of Physiotherapy. 2012; 58(3):157-63. [DOI:10.1016/S1836-9553(12)70106-6]

[53] Montgomery P, Dennis J. A systematic review of non-pharmacological therapies for sleep problems in later life. Sleep Medicine Reviews. 2004; 8(1):47-62. [DOI:10.1016/S1087-0792(03)00026-1]

[54] Khajavi D, Khanmohamadi R. The effect of "green exercise" on improving the sleep quality of female elderly without regular physical activity in Arak City. Journal of Woman and Family Studies. 2016; 3(2):7-32. 
This Page Intentionally Left Blank 